\title{
Total Synthesis of Cyclic Tetrapeptide FR235222, a Potent Immunosuppressant that Inhibits Mammalian Histone Deacetylases
}

\author{
Weiqing Xie, ${ }^{a}$ Bin Zou, ${ }^{a}$ Duanqing $\mathrm{Pei}^{\mathrm{b}}$ and Dawei Ma ${ }^{\mathrm{a} *}$ \\ ${ }^{a}$ State Key Laboratory of Bioorganic and Natural Products Chemistry, Shanghai \\ Institute of Organic Chemistry, Chinese Academy of Sciences, 354 Fenglin Lu, \\ Shanghai 200032, China, ${ }^{b}$ Department of Pharmacology, University of Minnesota, \\ Minneapolis, MN 55455, USA
}

Supporting Information

Table of content

Experimental----------------------------------------------------------------------S2

${ }^{1} \mathrm{H}$ NMR \& ${ }^{13} \mathrm{C}$ NMR spectra of compounds 5-9, 11-14, 17-20 and 1--S15 


\section{Experimental}

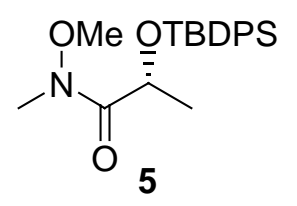

Amide 5. To a solution of methyl $(R)$-lactate $(1.9 \mathrm{~mL}, 20 \mathrm{mmol})$ and imidazole $(3.26 \mathrm{~g}, 48 \mathrm{mmol})$ in $60 \mathrm{~mL}$ of $\mathrm{CH}_{2} \mathrm{Cl}_{2}$ was added TBDPSCl $(6.14 \mathrm{~mL}, 24$ mmol) at $0{ }^{\circ} \mathrm{C}$. The resultant solution was stirred at room temperature overnight before it was washed with $1 \mathrm{M} \mathrm{HCl}$, saturated aqueous $\mathrm{NaHCO}_{3}$ and brine, respectively. The solution was dried over $\mathrm{Na}_{2} \mathrm{SO}_{4}$, and concentrated in vacuo. The resulting oil was purified by chromatography to afford $6.569 \mathrm{~g}$ of silyl ether.

To a solution of above silyl ether $(4.0 \mathrm{~g}, 11.7 \mathrm{mmol})$ in $180 \mathrm{~mL}$ of THF at $0{ }^{\circ} \mathrm{C}$ was added an ice-cooled solution of $\mathrm{LiOH}(0.2 \mathrm{M}, 23.4 \mathrm{mmol})$. After being stirred overnight, the mixture was acidified to $\mathrm{pH}=3$ and extracted three times with ethyl acetate. The combined organic layer was dried over $\mathrm{Na}_{2} \mathrm{SO}_{4}$, and concentrated in vacuo to give the crude acid, which was dissolved in $100 \mathrm{~mL} \mathrm{CH}_{2} \mathrm{Cl}_{2}$. To this solution were added $\mathrm{N}, \mathrm{O}$-dimethylhydroxyamine hydrocloride $(12 \mathrm{mmol}), \mathrm{EDC}(15 \mathrm{mmol})$ and DIPEA (15 mmol). The resulting solution was stirred overnight and concentrated in vacuo. The residue was purified by chromatography eluting with 1/6 ethyl acetate/petroleum ether to give $2.91 \mathrm{~g}$ of $\mathbf{5}$ as white solid in $67 \%$ yield. $[\alpha]_{\mathrm{D}}{ }^{25}=+12.1$ (c 1.4, $\left.\mathrm{CHCl}_{3}\right) ;{ }^{1} \mathrm{H} \mathrm{NMR}\left(300 \mathrm{MHz}, \mathrm{CDCl}_{3}\right) \delta$ 7.73-7.70 (m, 4H), 7.47-7.34 (m, 6H), $4.53(\mathrm{q}, J=6.6 \mathrm{~Hz}, 1 \mathrm{H}), 3.08(\mathrm{br} \mathrm{s}, 3 \mathrm{H}), 3.04(\mathrm{~s}, 3 \mathrm{H}), 1.38(\mathrm{~d}, J=6.6 \mathrm{~Hz}, 3 \mathrm{H}), 1.09(\mathrm{~s}$, $9 \mathrm{H}) ;{ }^{13} \mathrm{C} \mathrm{NMR}\left(300 \mathrm{MHz}, \mathrm{CDCl}_{3}\right) \delta 136.1,135.8,133.9,133.6,129.7,127.6,127.5$, 66.8, 60.6, 32.2, 26.9, 20.8, 19.3; ESI-MS $m / z, 461(\mathrm{M}+\mathrm{H})^{+}, 477(\mathrm{M}+\mathrm{K})^{+}$; HRMS 
Calcd.for $\mathrm{C}_{25} \mathrm{H}_{30} \mathrm{~N}_{2} \mathrm{O}_{5} \mathrm{Na}(\mathrm{M}+\mathrm{Na})^{+}$requires 461.2047, found 461.2050.

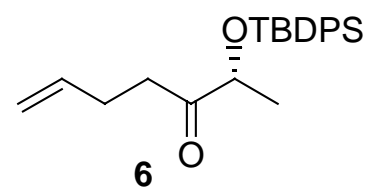

(R)-2-(tert-Butyldiphenylsiloxy)-6-hepten-3-one 6. To a stirred solution of the amide 5 (1.33 g, $3.58 \mathrm{mmol})$ in $25 \mathrm{~mL}$ dried THF was added a solution of 3-butenylmagnesium bromide [prepared from $\mathrm{Mg}(517 \mathrm{mg}, 21.5 \mathrm{mmol})$ and 1-bromo-3-butene $(1.094 \mathrm{~mL}, 10.78 \mathrm{mmol})]$ at $0{ }^{\circ} \mathrm{C}$. The resultant solution was stirred at room temperature for $3 \mathrm{~h}$ before $10 \%$ aqueous $\mathrm{HCl}$ was added to quench the reaction. The organic layer was separated and the aqueous layer was extracted with $\mathrm{Et}_{2} \mathrm{O}$ twice. The combined extracts was dried over $\mathrm{Na}_{2} \mathrm{SO}_{4}$ and concentrated. The residue was purified by chromatography eluting with $1 / 35$ ethyl acetate/petroleum ether to give $1.169 \mathrm{~g}$ of $6(89 \%) .[\alpha]_{\mathrm{D}}{ }^{20}=+18.1\left(c 1.2, \mathrm{CHCl}_{3}\right) ;{ }^{1} \mathrm{H} \mathrm{NMR}(300 \mathrm{MHz}$, $\left.\mathrm{CDCl}_{3}\right) \delta$ 7.67-4.93 (m, 4H), 7.46-7.25 (m, 6H), 5.84-5.70 (m, 1H), 5.03-4.93 (m, 2H), $4.20(\mathrm{q}, J=7.2 \mathrm{~Hz}, 1 \mathrm{H}), 2.66(\mathrm{dt}, J=2.1,7.5 \mathrm{~Hz}, 2 \mathrm{H}), 2.27-2.22(\mathrm{~m}, 2 \mathrm{H}), 1.19(\mathrm{~d}, J=$ $6.9 \mathrm{~Hz}, 3 \mathrm{H}), 1.09$ (s, 9H); ${ }^{13} \mathrm{C} \mathrm{NMR}\left(300 \mathrm{MHz}, \mathrm{CDCl}_{3}\right) \delta 212.4,137.4,135.8,133.0$, 130.0, 129.9, 127.8, 127.7, 115.0, 75.6, 36.4, 27.1, 27.0, 20.8, 19.3; ESI-MS m/z 461 $(\mathrm{M}+\mathrm{H})^{+}, 477(\mathrm{M}+\mathrm{K})^{+}$; HRMS Calcd. for $\mathrm{C}_{25} \mathrm{H}_{30} \mathrm{~N}_{2} \mathrm{O}_{5} \mathrm{Na}(\mathrm{M}+\mathrm{Na})^{+}$requires 461.2047, found: 461.2050 .

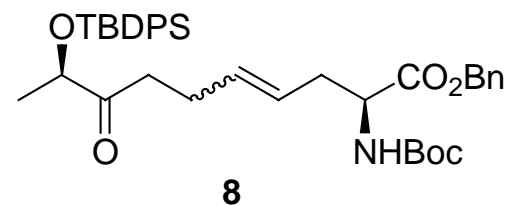


(2S,9R,5E)-9-(tert-Butyldiphenylsiloxy)-8-oxo-2-(tert-butoxycarbonyl)-

amine-5-decen-1-oic acid benzyl ester and (2S,9R,5Z)-9-(tert-butyldiphenylsiloxy)-8-oxo-2-(tert-butoxycarbonyl)-amine-5-decen-1-oic acid benzyl ester 8. To a solution of $6(216 \mathrm{mg}, 0.59 \mathrm{mmol})$ and amino ester $7(540 \mathrm{mg}, 1.77 \mathrm{mmol})$ in 2.3 $\mathrm{mL}$ 1,2-dichloroethane was added ruthenium catalyst $\mathbf{A}(25 \mathrm{mg})$. A steady nitrogen stream was blown over the top of the solution, and the mixture was stirred at room temperature for 7 days. The solution was concentrated in vacuo and the residue was purified by chromatography eluting with $1 / 35$ to $1 / 10$ ethyl acetate/petroleum ether to give $208 \mathrm{mg}$ of $\mathbf{8}$ as a light yellow oil in $55 \%$ yield: ${ }^{1} \mathrm{H} \mathrm{NMR}\left(300 \mathrm{MHz}, \mathrm{CDCl}_{3}\right) \delta$ 7.65-7.60 (m, 4H), 7.47-7.35 (m, 11H), 5.45-5.30 (m, 1H), 5.27-5.09 (m, 3H), 5.01 (d, $J=8.1 \mathrm{~Hz}, 1 \mathrm{H}), 4.40-4.33(\mathrm{~m}, 1 \mathrm{H}), 4.18(\mathrm{q}, J=6.9 \mathrm{~Hz}, 1 \mathrm{H}), 2.55(\mathrm{t}, J=6.9 \mathrm{~Hz}, 2 \mathrm{H})$, 2.46-2.38 (m, 2H), 2.16-2.09 (m, 2H), 1.43, $1.41(2 \mathrm{~s}, 9 \mathrm{H}), 1.18(\mathrm{~d}, J=6.6 \mathrm{~Hz}, 3 \mathrm{H})$, $1.10(\mathrm{~s}, 9 \mathrm{H})$; ESI-MS m/z $666(\mathrm{M}+\mathrm{Na})^{+}$; HRMS Calcd. for $\mathrm{C}_{38} \mathrm{H}_{49} \mathrm{NO}_{6} \mathrm{SiNa}(\mathrm{M}+$ $\mathrm{Na})^{+}$requires 666.3222 , found 666.3220 .

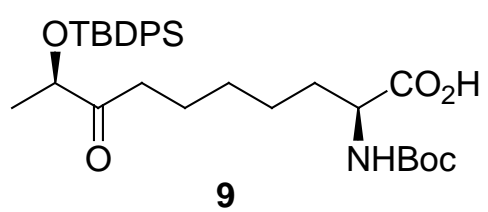

(2S,9R)-9-(tert-Butyldiphenylsiloxy)-8-oxo-2-(tert-butoxycarbonyl)amine-

decanoic acid. A solution of $8(241 \mathrm{mg}, 0.37 \mathrm{mmol})$ in $5 \mathrm{~mL} \mathrm{MeOH}$ was hydrogenated for $6 \mathrm{~h}$ at $1 \mathrm{~atm}$ in the presence of $48 \mathrm{mg} \mathrm{Pd} / \mathrm{C}$. The catalyst was filtered off and the filtrate was concentrated to give $196 \mathrm{mg}(94 \%) \mathbf{9}$ as a light yellow oil. $[\alpha]_{\mathrm{D}}^{21}=+18.2\left(c 1.0, \mathrm{CHCl}_{3}\right) ;{ }^{1} \mathrm{H}$ NMR $\left(300 \mathrm{MHz}, \mathrm{CDCl}_{3}\right) \delta$ 7.65-7.59 (m, 4H), 
7.46-7.33 (m, 6H), $5.50(\mathrm{~d}, J=8.4 \mathrm{~Hz}, 1 \mathrm{H}), 4.31-4.24(\mathrm{~m}, 1 \mathrm{H}), 4.19(\mathrm{q}, J=6.6 \mathrm{~Hz}$, $1 \mathrm{H}), 2.51(\mathrm{t}, J=6.9 \mathrm{~Hz}, 2 \mathrm{H}), 1.90-1.74(\mathrm{~m}, 1 \mathrm{H}), 1.73-1.56(\mathrm{~m}, 1 \mathrm{H}), 1.40-1.30(\mathrm{~m}$, 4H), 1.27-1.21 (m, 2H), $1.19(\mathrm{~d}, J=6.9 \mathrm{~Hz}, 3 \mathrm{H}), 1.10(\mathrm{~s}, 9 \mathrm{H}) ;{ }^{13} \mathrm{C}$ NMR $(300 \mathrm{MHz}$, $\left.\mathrm{CDCl}_{3}\right) \delta 213.3,177.2,155.7,135.8,133.6,133.0,130.0,129.9,127.8,127.7,53.3$, 37.0, 32.2, 28.8, 28.3, 26.9, 25.2, 22.8, 20.7, 19.2; ESI-MS $m / z 554(\mathrm{M}-\mathrm{H})^{+}$; HRMS Calcd. for $\mathrm{C}_{31} \mathrm{H}_{45} \mathrm{NO}_{6} \mathrm{SiNa}(\mathrm{M}+\mathrm{Na})^{+}$requires 578.2908, found 578.2909.<smiles>CCCCOCC1C[C@H](C(=O)OCc2ccccc2)NC1=O</smiles>

11<smiles>CCCCOC[C@H]1C[C@H](C(=O)OCc2ccccc2)NC1=O</smiles>

12

(3R,5R)-1-(tert-Butoxycarbonyl)-3-(tert-butyldimethylsiloxy)methyl-5-

benzoxycarbonyl-pyrrolidin-2-one 11 and (3R,5R)-1-(tert-Butoxycarbonyl)-3(tert-butyldimethylsiloxy)methyl-5-benzoxycarbonyl-pyrrolidin-2-one $12 . \mathrm{TiCl}_{4}$ (1.1 $\mathrm{mL}, 1.1 \mathrm{mmol}$ ) was added in 5 minutes to a solution of protected (R)-pyroglutamic acid $10(319 \mathrm{mg}, 1 \mathrm{mmol})$ in $5 \mathrm{~mL}$ of $\mathrm{CH}_{2} \mathrm{Cl}_{2}$ at $-78{ }^{\circ} \mathrm{C}$ to get a yellow slurry, then DIPEA $(0.74 \mathrm{~mL}, 4.4 \mathrm{mmol})$ was slowly added to give a violet solution. The mixture was stirred at $-78{ }^{\circ} \mathrm{C}$ for $3 \mathrm{~h}$, and gaseous formaldehye (generated by heating paraformaldehyde at $150{ }^{\circ} \mathrm{C}$ ) was slowly bubbled into the mixture in a flow of $\mathrm{N}_{2}$ for 30 min. The reaction was quenched by adding $2 \mathrm{~mL}$ saturated aqueous $\mathrm{NH}_{4} \mathrm{Cl}$ at $-78{ }^{\circ} \mathrm{C}$, then the solution was allowed to warm up to room temperature. The aqueous layer was separated and the organic layer was washed with brine, dried over $\mathrm{Na}_{2} \mathrm{SO}_{4}$ and concentrated. The residue was purified by 
chromatography eluting with $2 / 3$ ethyl acetate/petroleum ether to give $203 \mathrm{mg}$ (58\%) of aldol adducts.

The above aldol adducts (203 $\mathrm{mg}, 58 \mathrm{mmol}$ ) was dissolved in $4 \mathrm{~mL}$ of DMF and then imidazole (122 mg, $1.79 \mathrm{mmol}$ ) was added, followed by TBSCl ( $107 \mathrm{mg}$, $0.71 \mathrm{mmol}$ ) under argon. The mixture was stirred at room temperature for $6 \mathrm{~h}$ before it was was poured into $10 \mathrm{~mL}$ of water. The aqueous layer was extracted with ethyl acetate $(3 \times 10 \mathrm{~mL})$, and the combined organic layer was washed successively with water and brine, dried over $\mathrm{Na}_{2} \mathrm{SO}_{4}$, and concentrated. The residue was purified by chromatography eluting with 1/12 ethyl acetate/petroleum ether to give $141 \mathrm{mg} \mathbf{1 1}$ $(53 \%)$ and $84 \mathrm{mg} 12(31 \%) .11:[\alpha]_{\mathrm{D}}{ }^{25}=+23.7\left(c 1.0, \mathrm{CHCl}_{3}\right) ;{ }^{1} \mathrm{H}$ NMR $(300 \mathrm{MHz}$, $\left.\mathrm{CDCl}_{3}\right) \delta 7.38-7.35(\mathrm{~m}, 5 \mathrm{H}), 5.20(\mathrm{dd}, J=12.6,16.8 \mathrm{~Hz}, 2 \mathrm{H}), 4.61(\mathrm{dd}, J=3.0,9.6$ $\mathrm{Hz}, 1 \mathrm{H}), 3.95(\mathrm{dd}, J=4.5,10.2 \mathrm{~Hz}, 1 \mathrm{H}), 3.77(\mathrm{dd}, J=3.6,10.2 \mathrm{~Hz}, 1 \mathrm{H}), 2.70-2.79(\mathrm{~m}$, 1H), 2.33-2.43 (m, 1H), 2.05-2.14 (m, 1H), $1.42(\mathrm{~s}, 9 \mathrm{H}), 0.85(\mathrm{~s}, 9 \mathrm{H}), 0.03(\mathrm{~s}, 3 \mathrm{H})$, $0.04(\mathrm{~s}, 3 \mathrm{H}) ;{ }^{13} \mathrm{C} \mathrm{NMR}\left(300 \mathrm{MHz}, \mathrm{CDCl}_{3}\right) \delta 173.4,171.4,149.2,135.1,128.6,128.5$, 128.4, 83.4, 67.2, 62.2, 57.7, 44.6, 27.8, 25.8, 25.0, 18.1, -5.6; ESI-MS m/z $486(\mathrm{M}+$ $\mathrm{Na})^{+}$; HRMS Calcd. for $\mathrm{C}_{24} \mathrm{H}_{37} \mathrm{NO}_{6} \mathrm{SiNa}(\mathrm{M}+\mathrm{Na})^{+}$requires 486.2282, found 486.2279. 12: $[\alpha]_{\mathrm{D}}{ }^{25}=+4.0\left(c 0.9, \mathrm{CHCl}_{3}\right) ;{ }^{1} \mathrm{H} \mathrm{NMR}\left(300 \mathrm{MHz}, \mathrm{CDCl}_{3}\right) \delta$ 7.38-7.35 $(\mathrm{m}, 5 \mathrm{H}), 5.20(\mathrm{dd}, J=12.3,9.5 \mathrm{~Hz}, 2 \mathrm{H}), 4.57(\mathrm{dd}, J=7.2,9.3 \mathrm{~Hz}, 1 \mathrm{H}), 3.88-3.79(\mathrm{~m}$, $1 \mathrm{H}), 3.82-3.72(\mathrm{~m}, 1 \mathrm{H}), 2.52-2.41(\mathrm{~m}, 1 \mathrm{H}), 2.12-2.03(\mathrm{~m}, 1 \mathrm{H}), 1.42(\mathrm{~s}, 9 \mathrm{H}), 0.85(\mathrm{~s}$, 9H), $0.03(\mathrm{~s}, 6 \mathrm{H}) ;{ }^{13} \mathrm{C} \mathrm{NMR}\left(300 \mathrm{MHz}, \mathrm{CDCl}_{3}\right) \delta 172.9,171.2,149.3,135.1,128.6$, 128.5, 128.4, 83.6, 67.2, 61.9, 57.5, 45.6, 27.8, 25.8, 24.25, 18.2, -5.5; ESI-MS m/z $486(\mathrm{M}+\mathrm{Na})^{+}$, HRMS Calcd. for $\mathrm{C}_{24} \mathrm{H}_{37} \mathrm{NO}_{6} \mathrm{SiNa}(\mathrm{M}+\mathrm{Na})^{+}$requires 486.2282, 
found 486.2280

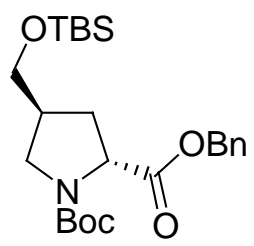

13

$(2 R, 4 S)$-1-(tert-Butoxycarbonyl)-2-benzoxycarbonyl-4-(tert-butyldimethyl-

siloxy)methylpyrrolidine 13. To a solution of $\mathbf{1 1}(1.068 \mathrm{~g}, 2.31 \mathrm{mmol})$ in $25 \mathrm{~mL}$ THF was added DIBALH (1 $\mathrm{M}$ in toluene, $5.77 \mathrm{~mL})$ at $-78{ }^{\circ} \mathrm{C}$. The mixture was stirred at $-78{ }^{\circ} \mathrm{C}$ for $1 \mathrm{~h}$, then quenched by adding $4 \mathrm{~mL}$ water, and the solution was warmed up to room temperature over $1 \mathrm{~h}$. The solution was dried over $\mathrm{Na}_{2} \mathrm{SO}_{4}$ and concentrated. The resulting residue was used without further purification.

The above product was dissolved in $25 \mathrm{~mL}$ of $\mathrm{CH}_{2} \mathrm{Cl}_{2}$ and cooled to $-78{ }^{\circ} \mathrm{C}$, then $\mathrm{Et}_{3} \mathrm{SiH}(441 \mu \mathrm{L}, 2.77 \mathrm{mmol})$ was added, followed by $\mathrm{BF}_{3} \cdot \mathrm{Et}_{2} \mathrm{O}(377 \mu \mathrm{L}, 3.0$ mmol). The mixture was stirred at $-78{ }^{\circ} \mathrm{C}$ for $30 \mathrm{~min}$, then $\mathrm{Et}_{3} \mathrm{SiH}(441 \mu \mathrm{L}, 2.77$ mmol $)$ and $\mathrm{BF}_{3} \cdot \mathrm{Et}_{2} \mathrm{O}(377 \mu \mathrm{L}, 3.0 \mathrm{mmol})$ was added successively. The stirring was continued at $-78{ }^{\circ} \mathrm{C}$ for another $1 \mathrm{~h}$ before saturated aqueous $\mathrm{NaHCO}_{3}(4 \mathrm{~mL})$ was added to quenched the reaction. The mixture was allowed to warm up to room temperature and then separated. The aqueous layer was extracted with $\mathrm{CH}_{2} \mathrm{Cl}_{2}$. The combined organic layer was dried over $\mathrm{Na}_{2} \mathrm{SO}_{4}$ and concentrated. The residue was purified by chromatography eluting with 1/5 ethyl acetate/petroleum ether to give 987 $\operatorname{mg}(95 \%)$ of $\mathbf{1 3}$ as a colorless oil. $[\alpha]_{\mathrm{D}}{ }^{25}=+24.4\left(c 0.8, \mathrm{CHCl}_{3}\right) ;{ }^{1} \mathrm{H} \mathrm{NMR}(300 \mathrm{MHz}$, $\left.\mathrm{CDCl}_{3}\right) \delta 7.33-7.27(\mathrm{~m}, 5 \mathrm{H}), 5.25-5.04(\mathrm{~m}, 2 \mathrm{H}), 4.30$ and 4.42 (both $\mathrm{dd}, J=4.8,6.6$ $\mathrm{Hz}$ and $J=8.4,3.6 \mathrm{~Hz}, 1 \mathrm{H}), 3.69-3.60(\mathrm{~m}, 1 \mathrm{H}), 3.57-3.51(\mathrm{~m}, 2 \mathrm{H}), 3.25-3.17(\mathrm{~m}, 1 \mathrm{H})$, 
2.52-2.42 (m, 1H), 2.14-1.96 (m, 2H), 1.45 and 1.33 (both s, 9H), $0.87(\mathrm{~s}, 9 \mathrm{H}), 0.02$ (s, $6 \mathrm{H}) ;{ }^{13} \mathrm{C} \mathrm{NMR}\left(300 \mathrm{MHz}, \mathrm{CDCl}_{3}\right) \delta 173.0$ and $172.8,154.8$ and $153.7,135.8$ and 135.6, 128.6, 128.5, 128.3, 128.1, 128.0, 79.9 and 79.8, 66.6, 63.9, 59.1 and 58.7, 48.8 and 48.6, 39.9 and 39.0, 33.0 and 32.1, 28.4 and 28.2, 25.8, 18.2, -5.5; ESI-MS $m / z, 472(\mathrm{M}+\mathrm{Na})^{+}$; HRMS Calcd. for $\mathrm{C}_{24} \mathrm{H}_{39} \mathrm{NO}_{5} \mathrm{SiNa}(\mathrm{M}+\mathrm{Na})^{+}$requires 472.2490, found 472.2489 .<smiles>CC1C[C@H](C(=O)OCc2ccccc2)N(C(=O)OCc2ccccc2)C1</smiles>

\section{(2R,4S)-1-(tert-Butoxycarbonyl)-2-benzoxycarbonyl-4-methylpyrrolidine}

14. To a solution of $\mathbf{1 3}(911 \mathrm{mg}, 2.03 \mathrm{mmol})$ in $20 \mathrm{~mL}$ of THF was added TBAF (1 $\mathrm{M}$ in THF, $4.06 \mathrm{~mL}$ ). The resultant mixture was stirred at room temperature for $3 \mathrm{~h}$ before it was concentrated under reduced pressure. The residue was purified by chromatography eluting with $1 / 4$ to $3 / 2$ ethyl acetate/petroleum ether to give $624 \mathrm{mg}$ $(91 \%)$ of alcohol.

To the above alcohol $(604 \mathrm{mg}, 1.79 \mathrm{mmol})$ in $20 \mathrm{~mL}$ of $\mathrm{CH}_{2} \mathrm{Cl}_{2}$ were added $\mathrm{Et}_{3} \mathrm{~N}(0.51 \mathrm{~mL}, 3.58 \mathrm{mmol})$, and $\mathrm{MsCl}(0.21 \mathrm{~mL}, 2.69 \mathrm{mmol})$ at $0{ }^{\circ} \mathrm{C}$. After the resultant solution was stirred for $3 \mathrm{~h}$ at the same temperature, it was washed with $1 \mathrm{M}$ $\mathrm{HCl}$, saturated aqueous $\mathrm{NaHCO}_{3}$ and brine, respectively. The solution was dried over $\mathrm{NaSO}_{4}$, and concentrated in vacuo. The residue was dissolved in $20 \mathrm{~mL}$ of DME and then $\mathrm{NaI}(2.75 \mathrm{~g}, 17.9 \mathrm{mmol})$ and $\mathrm{Zn}(1.192 \mathrm{~g}, 17.9 \mathrm{mmol})$ was added successively. The resultant mixture was refluxed under argon for $1 \mathrm{~h}$ and then cooled to room temperature. The mixture was filtered through celite to remove $\mathrm{Zn}$ and the 
filtrate was partitioned between $50 \mathrm{~mL}$ of ethyl acetate and $50 \mathrm{~mL}$ of water. The organic layer was washed with saturated $\mathrm{Na}_{2} \mathrm{~S}_{2} \mathrm{O}_{3}$ and dried over $\mathrm{Na}_{2} \mathrm{SO}_{4}$ and concentrated. The residue was purified by chromatography eluting with $1 / 10$ ethyl acetate/petroleum ether to give $550 \mathrm{mg} 14(96 \%)$ as a colorless oil. $[\alpha]_{\mathrm{D}}^{25}=+26.6(\mathrm{c}$ 1.2, $\left.\mathrm{CHCl}_{3}\right) ;{ }^{1} \mathrm{H}$ NMR $\left(300 \mathrm{MHz}, \mathrm{CDCl}_{3}\right) \delta$ 7.34-7.36 (m, 5H), 5.27-5.06 (m, 2H), 4.42 and 4.21 (both dd with $J=3.0,9.0 \mathrm{~Hz}, 1 \mathrm{H}), 3.76-3.64(\mathrm{~m}, 1 \mathrm{H}), 3.00-2.87$ (m, $1 \mathrm{H}), 3.43-2.31(\mathrm{~m}, 1 \mathrm{H}), 2.10-2.03(\mathrm{~m}, 1 \mathrm{H}), 1.91-1.78(\mathrm{~m}, 1 \mathrm{H}), 1.34$ and 1.46 (both s, 9H), 1.02 and 1.03 (both d with $J=6.6 \mathrm{~Hz}, 3 \mathrm{H}),{ }^{13} \mathrm{C} \mathrm{NMR}\left(300 \mathrm{MHz}, \mathrm{CDCl}_{3}\right) \delta 173.0$ and 172.8, 154.4 and 153.7, 135.8 and 135.6, 128.6, 128.3, 128.1, 128.0, 79.8 and 79.7, 66.6, 59.3 and 59.1, 53.5 and 53.1, 38.4 and 37.1, 32.0 and 31.1, 28.4 and 28.2, 17.4 and 17.3; ESI-MS m/z $342(\mathrm{M}+\mathrm{Na})^{+}$; HRMS Calcd. for $\mathrm{C}_{18} \mathrm{H}_{25} \mathrm{NO}_{4} \mathrm{Na}(\mathrm{M}+$ $\mathrm{Na})^{+}$requires 342.1676 , found 342.1675 .

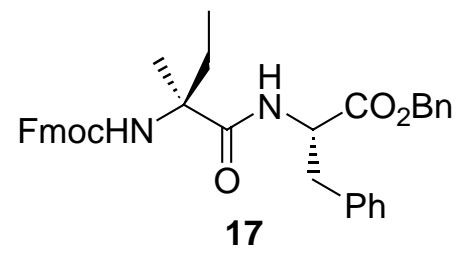

Dipeptide 17. To a solution of $(S)-2-(9 H$-Fluoren-9-ylmethoxycarbonylamino)-3-phenyl-propionic acid benzyl ester (4.86 g, $3.89 \mathrm{mmol})$ in $\mathrm{MeCN}$ (10 mL) was added $\mathrm{Et}_{2} \mathrm{NH}(5 \mathrm{~mL})$. The solution was stirred for $30 \mathrm{~min}$ and concentrated to dryness to afford $(S)$-phenylalanine benzyl ester 16. The amine was dissolved in dry $\mathrm{CH}_{2} \mathrm{Cl}_{2}(10 \mathrm{~mL})$ and Fmoc-isovaline acid 15 (1.1 g, $\left.3.24 \mathrm{mmol}\right)$, HOBt (0.526 g, 3.89 mmol), EDCI (0.748 g, $3.89 \mathrm{mmol})$ were added successively. To the resulting solution was added DIPEA $(1.4 \mathrm{~mL}, 3.89 \mathrm{mmol})$. The resulting mixture was stirred for $24 \mathrm{~h}$ 
and washed with $1 \mathrm{M} \mathrm{HCl}$, saturated aqueous $\mathrm{NaHCO}_{3}$, brine, and dried over $\mathrm{Na}_{2} \mathrm{SO}_{4}$, then concentrated in vacuo. The residue was purified by chromatography eluting with 1/7 ethyl acetate/petroleum ether to afford $1.67 \mathrm{~g}$ (90\%) of dipeptide $\mathbf{1 7}$ as a white solid. $[\alpha]_{\mathrm{D}}{ }^{23}=+3.5\left(c 1.2, \mathrm{CHCl}_{3}\right) ;{ }^{1} \mathrm{H} \mathrm{NMR}\left(300 \mathrm{MHz}, \mathrm{CDCl}_{3}\right) \delta 7.78(\mathrm{~d}, J=7.2 \mathrm{~Hz}$, 2H), 7.60 (d, J = 7.5 Hz, 2H), 7.44-7.25 (m, 8H), 7.21-7.19 (m, 4H), 7.00 (br s, 1H), $6.39(\mathrm{~d}, J=6.0 \mathrm{~Hz}, 1 \mathrm{H}), 5.68(\mathrm{br} \mathrm{s}, 1 \mathrm{H}), 5.22-5.08(\mathrm{~m}, 2 \mathrm{H}), 2.96(\mathrm{br} \mathrm{s}, 1 \mathrm{H}), 4.37$ (d, $J$ $=6.3 \mathrm{~Hz}, 2 \mathrm{H}), 4.20(\mathrm{~d}, J=6.9 \mathrm{~Hz}, 1 \mathrm{H}), 3.14($ br s, $2 \mathrm{H}), 2.16($ br s, $1 \mathrm{H}), 1.65$ (br s, 1H), 1.44 (br s, 3H), 0.75 (br s, 3H); ESIMS m/z $577(\mathrm{M}+\mathrm{H})^{+}$; HRMS Calcd. for $\mathrm{C}_{31} \mathrm{H}_{36} \mathrm{~N}_{2} \mathrm{O}_{5} \mathrm{Na}(\mathrm{M}+\mathrm{Na})^{+}$requires 599.2516, found 599.2717.

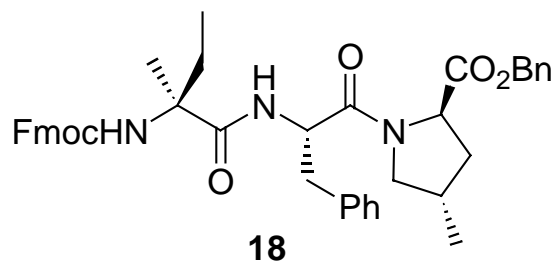

Tripeptide 18. A solution of $567 \mathrm{mg} 17 \mathrm{in} 7 \mathrm{~mL} \mathrm{MeOH}$ was hydrogenated for $6 \mathrm{~h}$ at $1 \mathrm{~atm}$ in the presence of $80 \mathrm{mg} \mathrm{Pd} / \mathrm{C}$. The solution was filtrated and concentrated to give $603 \mathrm{mg}(88 \%)$ of acid, which was used without further purification.

To a solution of $14(148 \mathrm{mg}, 0.46 \mathrm{mmol})$ in $3 \mathrm{~mL}$ of $\mathrm{CH}_{2} \mathrm{Cl}_{2}$ was added $1 \mathrm{~mL}$ of TFA. The solution was stirred for $30 \mathrm{~min}$ and concentrated to dryness. The residue was dissolved in dry $\mathrm{CH}_{2} \mathrm{Cl}_{2}(5 \mathrm{~mL})$ and then DIPEA $(0.31 \mathrm{~mL}, 1.64 \mathrm{mmol})$, the above acid (225 mg, $0.46 \mathrm{mmol}$ ), HOBt (94 mg, $0.69 \mathrm{mmol}$ ), EDCI (30 mg, 0.69 mmol) were added successively. The mixture was stirred overnight and washed with 1 $\mathrm{M} \mathrm{HCl}$, saturated aqueous $\mathrm{NaHCO}_{3}$, brine, and dried over $\mathrm{Na}_{2} \mathrm{SO}_{4}$, then concentrated 
in vacuo. The residue was purified by chromatography eluting with $1 / 3$ ethyl acetate/petroleum ether to afford $251 \mathrm{mg}(69 \%)$ of $\mathbf{1 8}$ as a white solid. $[\alpha]_{\mathrm{D}}^{23}=+25.4$ $\left(c 0.9, \mathrm{CHCl}_{3}\right) ;{ }^{1} \mathrm{H} \mathrm{NMR}\left(300 \mathrm{MHz}, \mathrm{CDCl}_{3}\right) \delta 7.76(\mathrm{~d}, J=8.1 \mathrm{~Hz}, 2 \mathrm{H}), 7.62(\mathrm{~d}, J=$ $7.5 \mathrm{~Hz}, 2 \mathrm{H}), 7.42-7.17(\mathrm{~m}, 14 \mathrm{H}), 7.02(\mathrm{~d}, J=7.5 \mathrm{~Hz}, 1 \mathrm{H}), 6.68(\mathrm{~d}, J=7.5 \mathrm{~Hz}, 1 \mathrm{H})$, 5.72 (br s, 1H), 5.14-5.03 (m, 2H), $4.93(\mathrm{~m}, 1 \mathrm{H}), 4.43(\mathrm{~d}, J=6.6 \mathrm{~Hz}, 2 \mathrm{H}), 4.36(\mathrm{~m}$, $1 \mathrm{H}), 4.23(\mathrm{t}, J=6.0 \mathrm{~Hz}, 1 \mathrm{H}), 3.72(\mathrm{~m}, 1 \mathrm{H}), 3.19-2.79(\mathrm{~m}, 3 \mathrm{H}), 2.29$ (br s, 1H), 2.16 (m, 2H), 1.99-1.92 (m, 1H), 1.68 (br s, 1H), 1.49 (br s, 1H), $0.78(\mathrm{~d}, J=6.3 \mathrm{~Hz}, 3 \mathrm{H})$, 0.75 (br s, 3H); ESIMS m/z $710(\mathrm{M}+\mathrm{Na})^{+}$; HRMS Calcd. for $\mathrm{C}_{42} \mathrm{H}_{45} \mathrm{~N}_{3} \mathrm{O}_{6} \mathrm{Na}(\mathrm{M}+$ $\mathrm{Na})^{+}$requires 710.3201 , found 710.3200 .

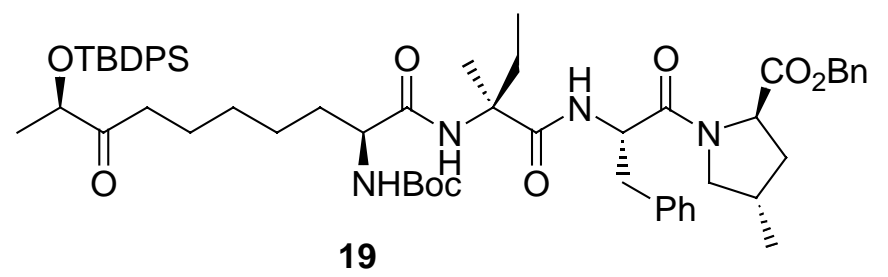

Tetrapeptide 19. The tripeptide 18 (41 $\mathrm{mg}, 0.06 \mathrm{mmol})$ in $1 \mathrm{~mL} \mathrm{MeCN}$ was treated with $0.5 \mathrm{~mL}$ of $\mathrm{Et}_{2} \mathrm{NH}$ for $30 \mathrm{~min}$. The solvent was removed and the residue was dissolved in $1 \mathrm{~mL}$ of $\mathrm{CH}_{2} \mathrm{Cl}_{2}$, then acid 9 (30 mg, $0.054 \mathrm{mmol}$ ), HOBt (11 mg, $0.081 \mathrm{mmol})$, EDCI (41 mg, $0.081 \mathrm{mmol})$, and DIPEA (0.023 mL, $0.136 \mathrm{mmol})$ were added successively. The mixture was stirred at room temperature for $24 \mathrm{~h}$ before it was washed with $1 \mathrm{M} \mathrm{HCl}$, saturated aqueous $\mathrm{NaHCO}_{3}$ and brine, respectively. The solution was dried over $\mathrm{Na}_{2} \mathrm{SO}_{4}$, and concentrated in vacuo. The residue was purified by chromatography eluting with $1 / 3$ ethyl acetate/petroleum ether to afford $42 \mathrm{mg}$ $(78 \%)$ of 19 as a white solid: $[\alpha]_{\mathrm{D}}^{23}=+48.5\left(c 1.0, \mathrm{CHCl}_{3}\right) ;{ }^{1} \mathrm{H}$ NMR $(300 \mathrm{MHz}$, $\left.\mathrm{CDCl}_{3}\right) \delta$ 7.65-7.60 (m, 4H), 7.44-7.32 (m, 10H), 7.26-7.18 (m, 6H), $7.00(\mathrm{~s}, 1 \mathrm{H})$, 
$6.73(\mathrm{~d}, J=7.2 \mathrm{~Hz}, 1 \mathrm{H}), 5.18-5.04(\mathrm{~m}, 3 \mathrm{H}), 4.97-4.89(\mathrm{~m}, 1 \mathrm{H}), 4.42(\mathrm{dd}, J=2.4,8.4$ $\mathrm{Hz}, 1 \mathrm{H}), 4.18(\mathrm{q}, J=7.2 \mathrm{~Hz}, 1 \mathrm{H}), 4.08-3.94(\mathrm{~m}, 1 \mathrm{H}), 3.72(\mathrm{t}, J=6.9 \mathrm{~Hz}, 1 \mathrm{H})$, 3.13-2.85 (m, 3H), $2.51(\mathrm{t}, J=7.2 \mathrm{~Hz}, 3 \mathrm{H}), 2.36-2.22(\mathrm{~m}, 2 \mathrm{H}), 2.17(\mathrm{t}, J=9.6 \mathrm{~Hz}$, $1 \mathrm{H}), 1.99-1.92(\mathrm{~m}, 1 \mathrm{H}), 1.82-1.63(\mathrm{~m}, 3 \mathrm{H}), 1.49(\mathrm{~s}, 3 \mathrm{H}), 1.43$ and $1.45(2 \mathrm{~s}, 9 \mathrm{H})$, 1.21-1.34 (m, 5H), $1.18(\mathrm{~d}, J=6.9 \mathrm{~Hz}, 3 \mathrm{H}), 1.01(\mathrm{~s}, 9 \mathrm{H}), 0.78(\mathrm{~d}, J=6.3 \mathrm{~Hz}, 3 \mathrm{H})$, $0.72(\mathrm{t}, J=7.2 \mathrm{~Hz}, 3 \mathrm{H})$; ESIMS m/z $1003(\mathrm{M}+\mathrm{H})^{+}, 1025(\mathrm{M}+\mathrm{Na})^{+}$; HRMS Calcd. for $\mathrm{C}_{58} \mathrm{H}_{78} \mathrm{~N}_{4} \mathrm{O}_{9} \mathrm{SiNa}(\mathrm{M}+\mathrm{Na})^{+}$requires 1025.5430, found 1025.5432.

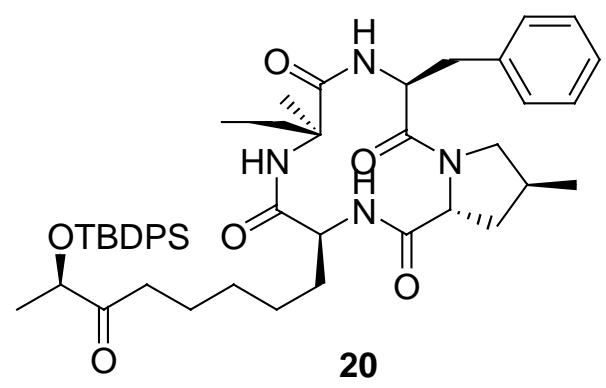

Cyclization of 19. Tetrapeptide 19 (180 mg, $0.18 \mathrm{mmol})$ was dissolved in 2 $\mathrm{mL} \mathrm{MeOH}$, and then $\mathrm{Pd} / \mathrm{C}(36 \mathrm{mg}, 20 \%)$ was added. The mixture was hydrogenated for $6 \mathrm{~h}$ at $1 \mathrm{~atm}$, then $\mathrm{Pd} / \mathrm{C}$ was filtrated and the filtrate was concentrated. The residue was dissolved in $2 \mathrm{~mL}$ of $\mathrm{CH}_{2} \mathrm{Cl}_{2}$, and $\mathrm{C}_{6} \mathrm{~F}_{5} \mathrm{OH}$ (99 mg, $\left.0.54 \mathrm{mmol}\right)$ and $\mathrm{EDC}$ (52 $\mathrm{mg}$, $0.27 \mathrm{mmol}$ ) were added successively. The mixture was stirred overnight and washed with $1 \mathrm{M} \mathrm{HCl}$, saturated aqueous $\mathrm{NaHCO}_{3}$ solution and brine, respectively. After it was dried over $\mathrm{Na}_{2} \mathrm{SO}_{4}$, the solution was concentrated in vacuo, and the residue was purified by chromatography eluting with 1/2 ethyl acetate/petroleum ether to give 149 mg $(77 \%)$ of activated ester.

To a solution of the above ester in $1.5 \mathrm{~mL}$ of $\mathrm{CH}_{2} \mathrm{Cl}_{2}$ was added TFA $(0.5 \mathrm{~mL})$. The mixture was stirred for $1 \mathrm{~h}$ before the solvent was removed under reduced 
pressure. The residue was dissolved in $20 \mathrm{~mL}$ of $\mathrm{CHCl}_{3}$ and added slowly (12 h) to a mixture of saturated aqueous $\mathrm{NHCO}_{3}$ solution $(100 \mathrm{~mL})$ and $\mathrm{CHCl}_{3}(80 \mathrm{~mL})$ through a syringe pump. After the mixture was stirred vigorously for another $12 \mathrm{~h}$. The organic layer was separated and the aqueous layer was washed with $\mathrm{CHCl}_{3}(50 \mathrm{~mL})$. The combined organic layer was dried over $\mathrm{Na}_{2} \mathrm{SO}_{4}$, and concentrated in vacuo. The residue was purified by chromatography eluting with $1 / 4$ then $1 / 2$ ethyl acetate/petroleum to afford $62 \mathrm{mg}(56 \%)$ of $\mathbf{2 0}$ as a white solid: $[\alpha]_{\mathrm{D}}^{23}=-69.5(c 0.7$, $\left.\mathrm{CHCl}_{3}\right) ;{ }^{1} \mathrm{H}$ NMR $\left(300 \mathrm{MHz}, \mathrm{CDCl}_{3}\right) \delta 7.65(\mathrm{~m}, 4 \mathrm{H}), 7.57(\mathrm{~d}, J=10.5,1 \mathrm{H}), 7.44-7.35$ (m, 6H), 7.31-7.20 (m, 5H), $7.159 \mathrm{~d}, J=10.8 \mathrm{~Hz}, 1 \mathrm{H}), 5.859 \mathrm{~s}, 1 \mathrm{H}), 5.21-5.12(\mathrm{~m}$, $1 \mathrm{H}), 4.67(\mathrm{~d}, J=7.2 \mathrm{~Hz}, 1 \mathrm{H}), 4.23-4.24(\mathrm{~m}, 2 \mathrm{H}), 4.07(\mathrm{t}, J=7.5 \mathrm{~Hz}, 1 \mathrm{H}), 3.25(\mathrm{dd}, J$ $=9.9,13.5 \mathrm{~Hz}, 1 \mathrm{H}), 2.96(\mathrm{dd}, J=6.0,13.5 \mathrm{~Hz}, 1 \mathrm{H}), 2.72(\mathrm{dd}, J=7.5,16.8 \mathrm{~Hz}, 1 \mathrm{H})$, 2.69-2.57 (m, 1H), 2.54-2.45 (m, 2H), 2.45-2.27 (m, 2H), 2.21-2.09 (m, 1H), 1.84-1.67 (m, 1H), 1.66-1.53 (m, 1H), 2.45-2.27 (m, 2H), 2.21-2.09 (m, 1H), 1.84-1.67 (m, 1H), 1.66-1.53 (m, 1H), 1.51-1.35 (m, 3H), $1.29(\mathrm{~s}, 3 \mathrm{H}), 1.27-1.21(\mathrm{~m}$, 4H), $1.18(\mathrm{~d}, J=6.3 \mathrm{~Hz}, 3 \mathrm{H}), 1.10(\mathrm{~s}, 9 \mathrm{H}), 0.88(\mathrm{~d}, J=6.3 \mathrm{~Hz}, 3 \mathrm{H}), 0.84(\mathrm{t}, J=7.2$ $\mathrm{Hz}, 3 \mathrm{H})$; ESIMS m/z $817(\mathrm{M}+\mathrm{Na})^{+}$; HRMS Calcd. for $\mathrm{C}_{46} \mathrm{H}_{62} \mathrm{~N}_{4} \mathrm{O}_{6} \mathrm{SiNa}(\mathrm{M}+\mathrm{Na})^{+}$ requires 817.4331 , found 817.4332 . 


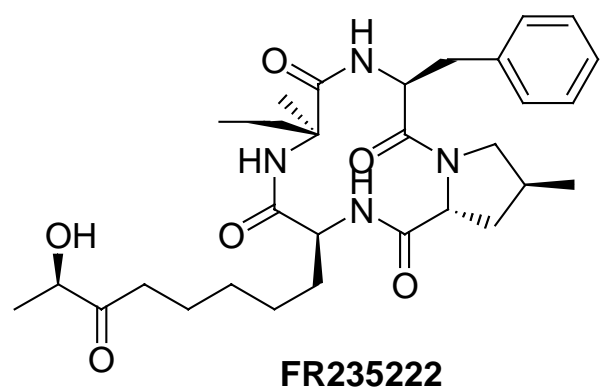

FR235222. To a solution of $\mathbf{1 9}(22 \mathrm{mg}, 0.03 \mathrm{mmol})$ in $1 \mathrm{~mL}$ of THF was added TBAF ( $1 \mathrm{M}$ in THF, $0.06 \mathrm{~mL})$. The mixture was stirred at room temperature for $1 \mathrm{~h}$ before it was concentrated. The residue was purified by flash chromatograph eluting with $1 / 1$ to $5 / 1$ ethyl acetate/petroleum to give $13 \mathrm{mg}(84 \%)$ of FR235222. $[\alpha]_{\mathrm{D}}{ }^{23}=-129.1\left(c 0.5, \mathrm{CHCl}_{3}\right) ;{ }^{1} \mathrm{H} \mathrm{NMR}\left(500 \mathrm{MHz}, \mathrm{CDCl}_{3}\right) \delta 7.52(\mathrm{~d}, J=10.2 \mathrm{~Hz}$ 1H), 7.29-7.20 (m, 5H), $7.17(\mathrm{~d}, J=10.6 \mathrm{~Hz}, 1 \mathrm{H}), 5.83(\mathrm{~s}, 1 \mathrm{H}), 5.16(\mathrm{ddd}, J=6.3,9.7$, $9.9 \mathrm{~Hz}, 1 \mathrm{H}), 4.24-4.17(\mathrm{~m}, 2 \mathrm{H}), 4.05(\mathrm{dd}, J=7.8,9.7 \mathrm{~Hz}, 1 \mathrm{H}), 3.54(\mathrm{~d}, J=4.5 \mathrm{~Hz}$, 1H), $3.24(\mathrm{dd}, J=9.9,13.6 \mathrm{~Hz}, 1 \mathrm{H}), 2.95(\mathrm{dd}, J=6.1,13.5 \mathrm{~Hz}, 1 \mathrm{H}), 2.73(\mathrm{t}, J=7.8$ $\mathrm{Hz}, 1 \mathrm{H}), 2.63(\mathrm{~m}, 1 \mathrm{H}), 2.54-2.28(\mathrm{~m}, 4 \mathrm{H}), 2.16(\mathrm{~m}, 1 \mathrm{H}), 1.80(\mathrm{~m}, 1 \mathrm{H}), 1.63(\mathrm{~m}, 3 \mathrm{H})$, $1.38(\mathrm{~d}, J=7.1 \mathrm{~Hz}, 3 \mathrm{H}), 1.33(\mathrm{~m}, 5 \mathrm{H}), 1.28(\mathrm{~s}, 3 \mathrm{H}), 0.88(\mathrm{~d}, J=6.7 \mathrm{~Hz}, 3 \mathrm{H}), 0.84(\mathrm{t}, J$ $=7.4 \mathrm{~Hz}, 3 \mathrm{H}) ;{ }^{13} \mathrm{C} \mathrm{NMR}\left(75 \mathrm{MHz}, \mathrm{CDCl}_{3}\right) \delta 214.4,175.6,171.1,171.8,137.1,129.1$, $128.6,126.7,72.6,63.1,58.0,54.5,53.9,53.4,37.3,35.8,33.1,32.9,28.8,27.9,25.3$, 23.3, 22.4, 19.9, 18.2, 16.5, 8.4; ESIMS m/z $557(\mathrm{M}+\mathrm{H})^{+}, 579(\mathrm{M}+\mathrm{Na})^{+}$; HRMS Calcd. for $\mathrm{C}_{30} \mathrm{H}_{44} \mathrm{~N}_{4} \mathrm{O}_{6} \mathrm{Na}(\mathrm{M}+\mathrm{Na})^{+}$requires 579.3158, found 579.3156. 

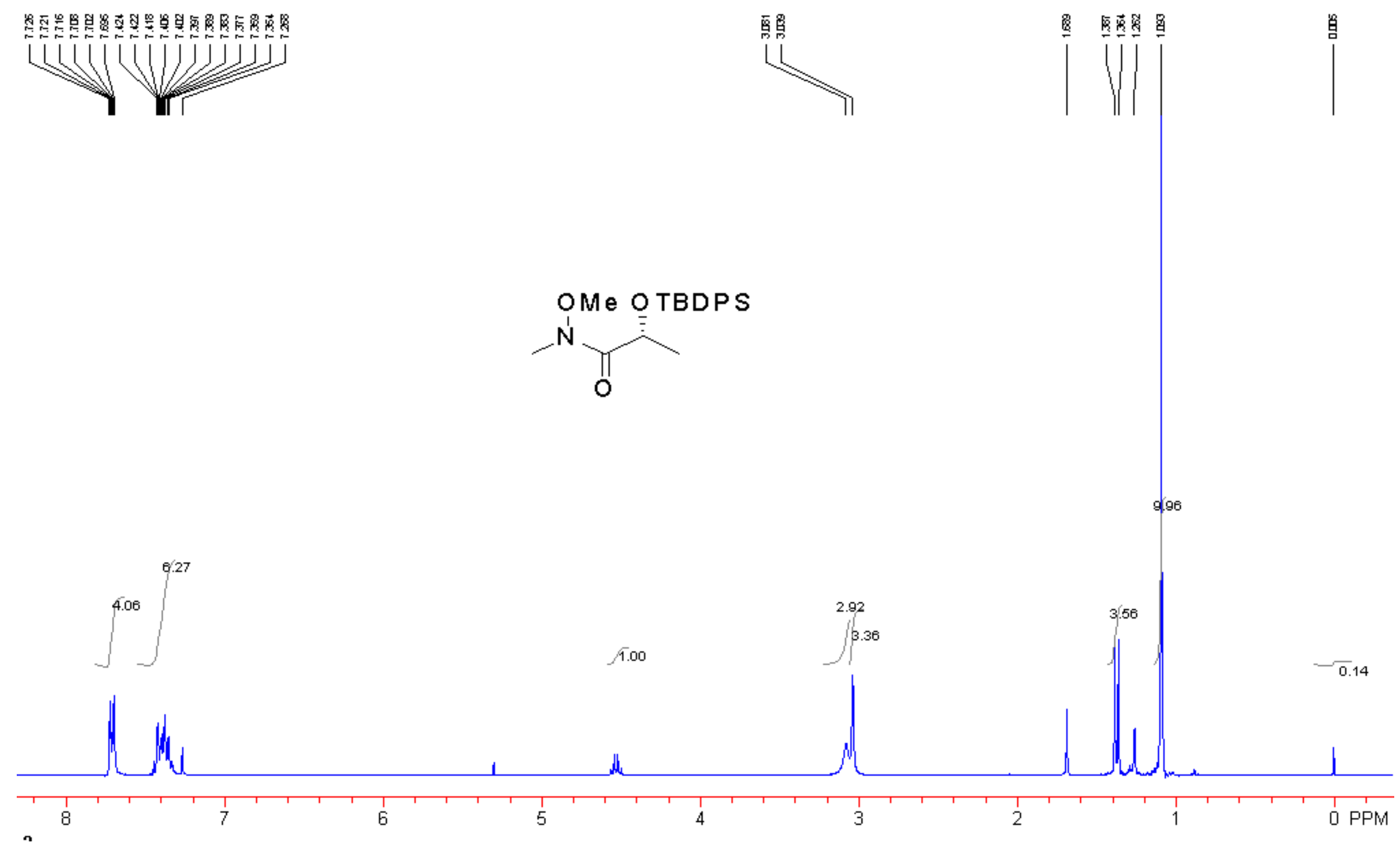


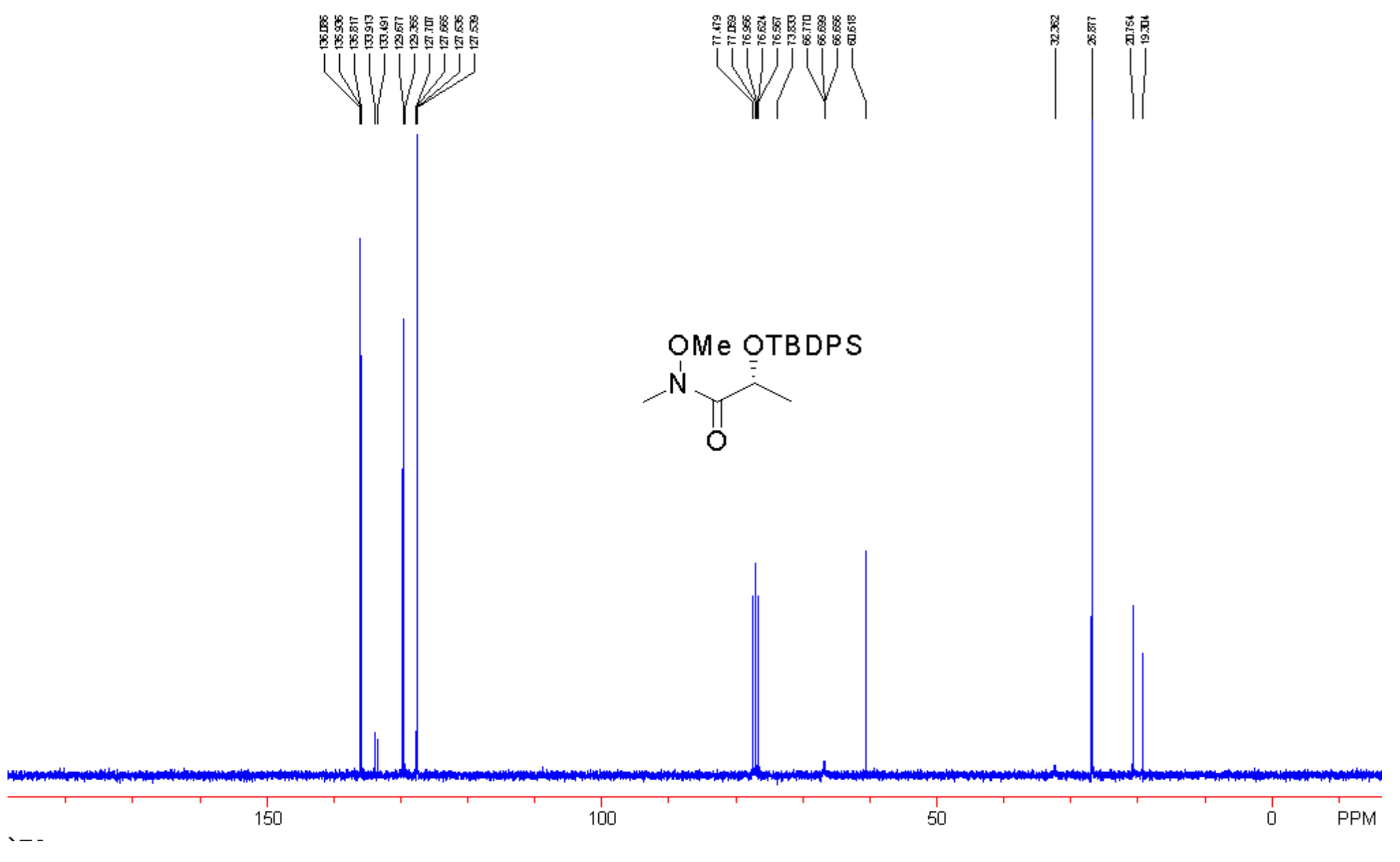



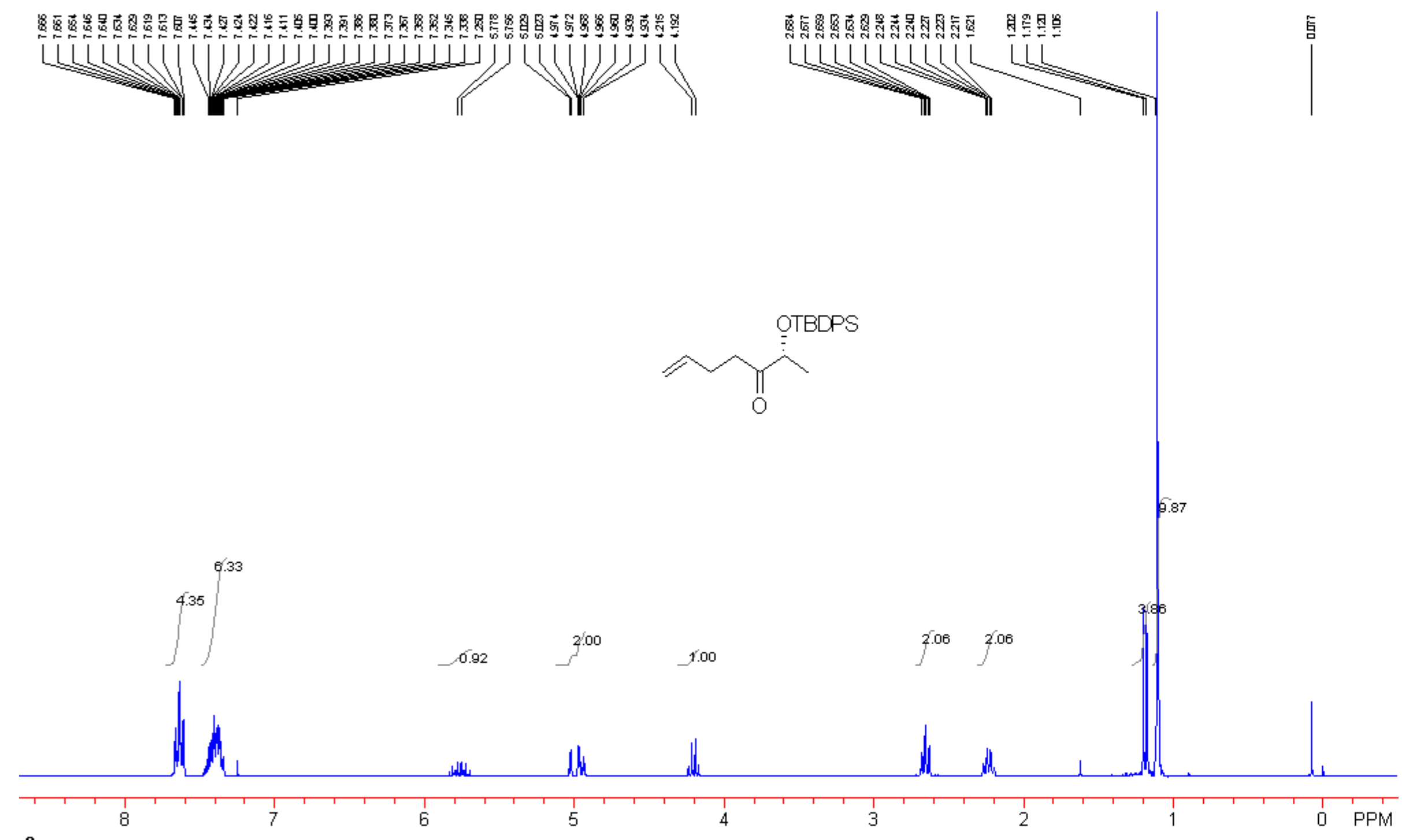


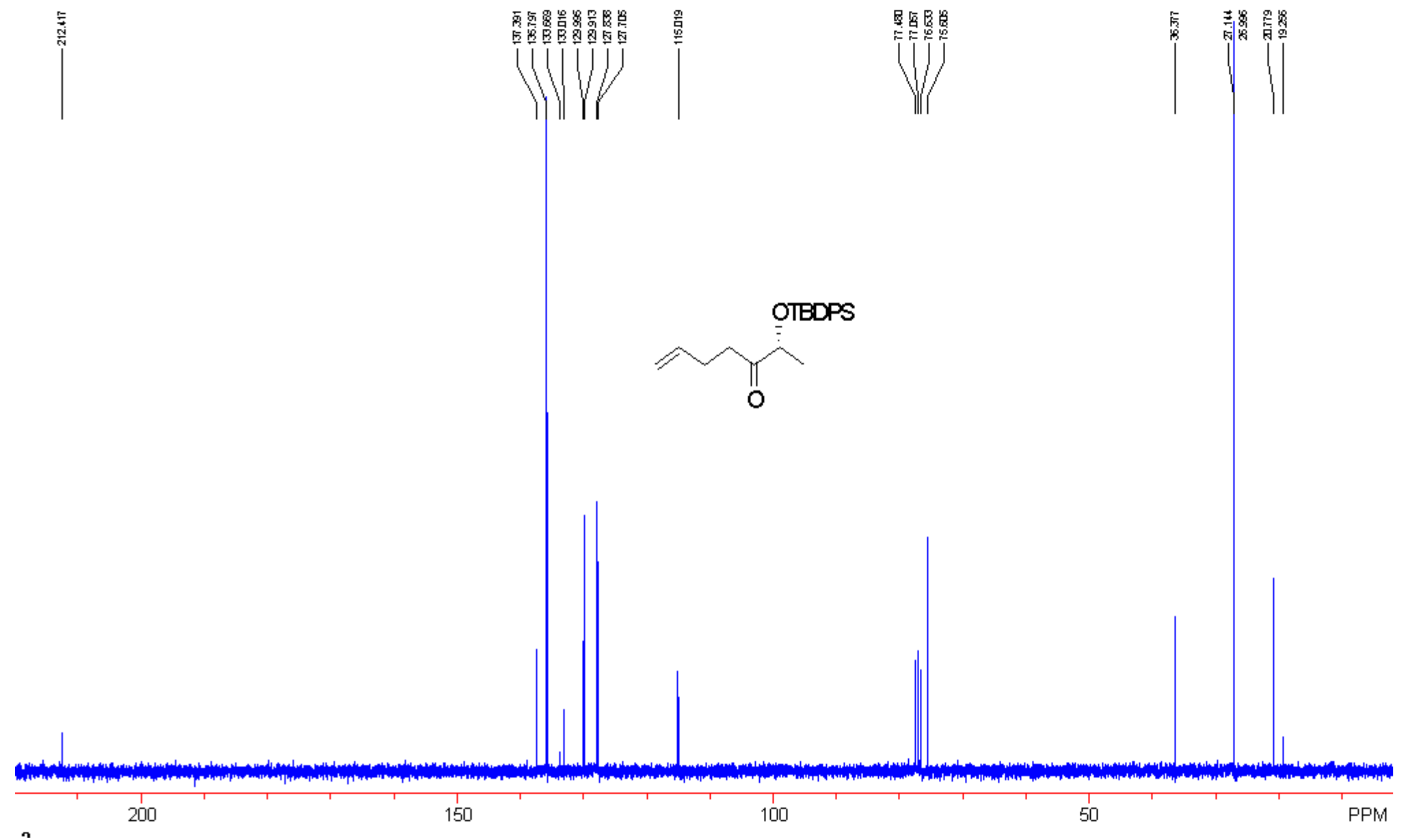



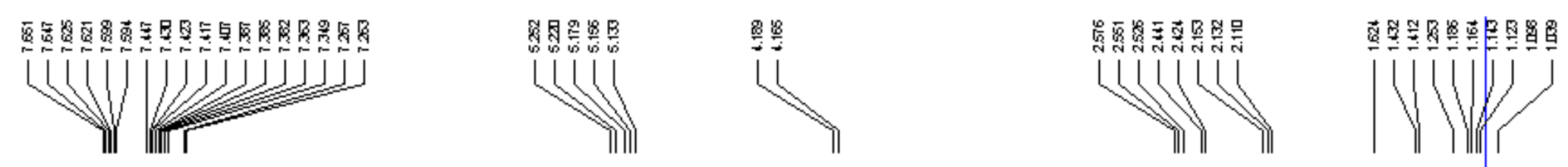

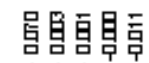
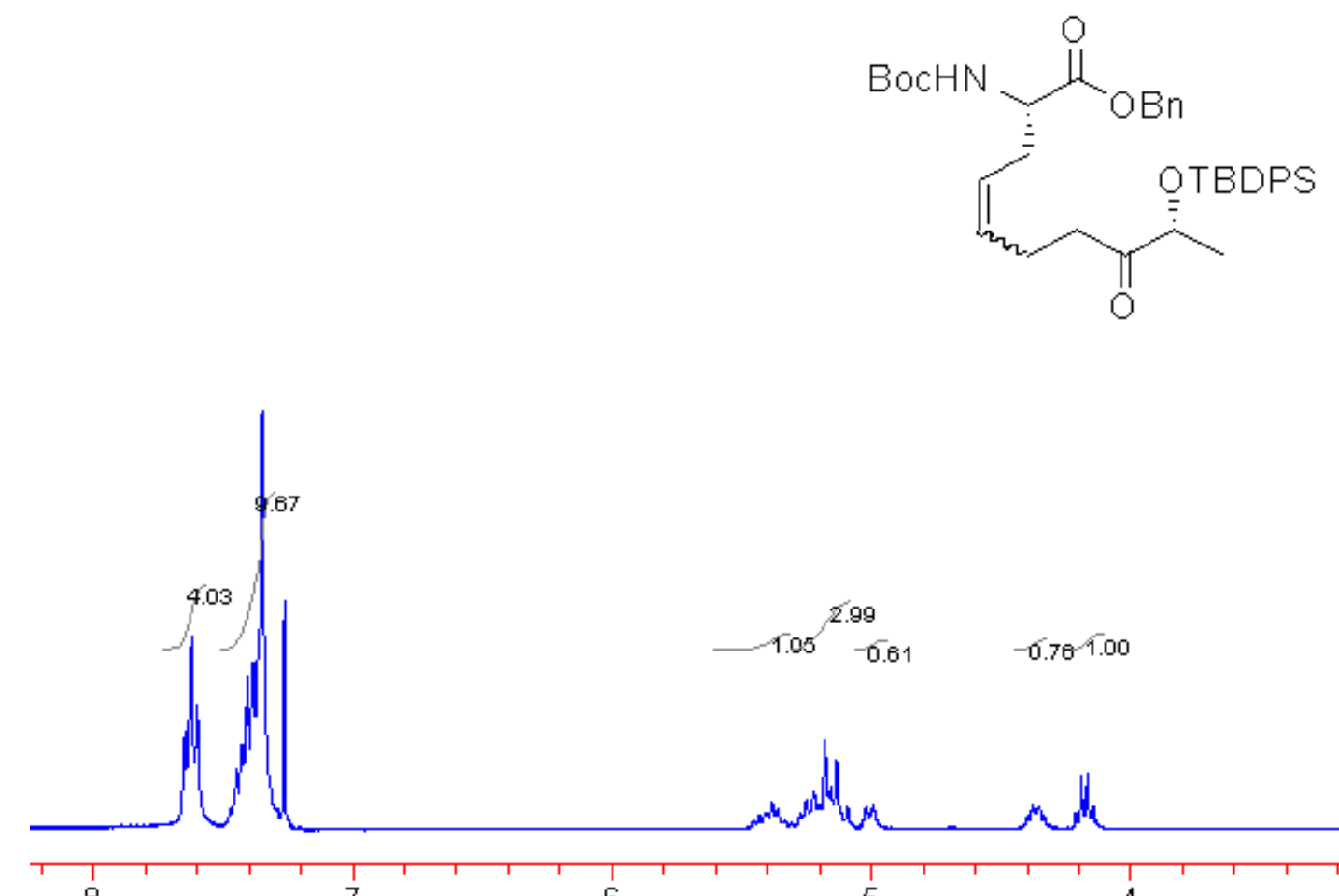

8

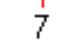

$-1.05^{2.99}$

$-6.701 .00$

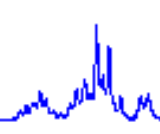

nh 


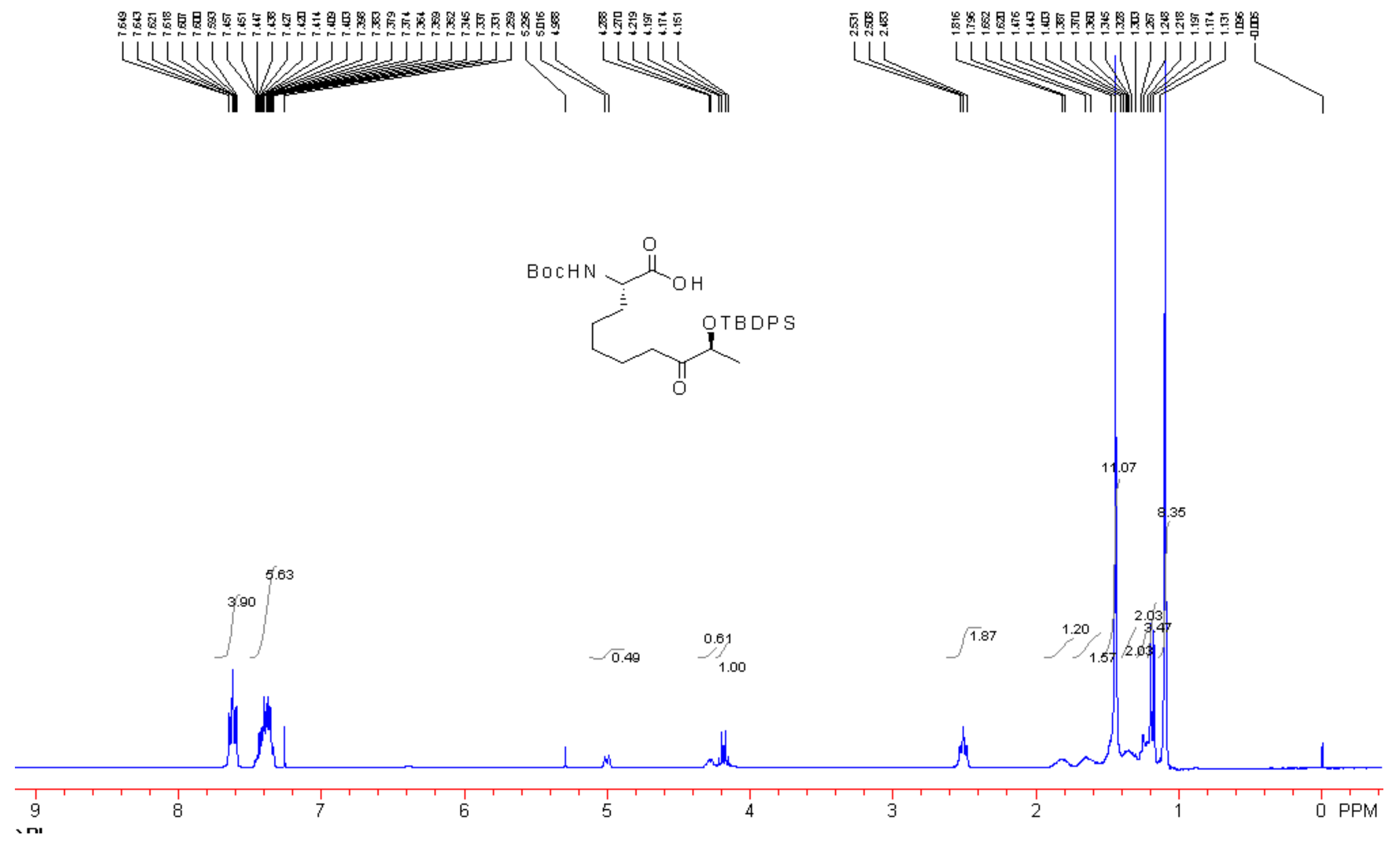




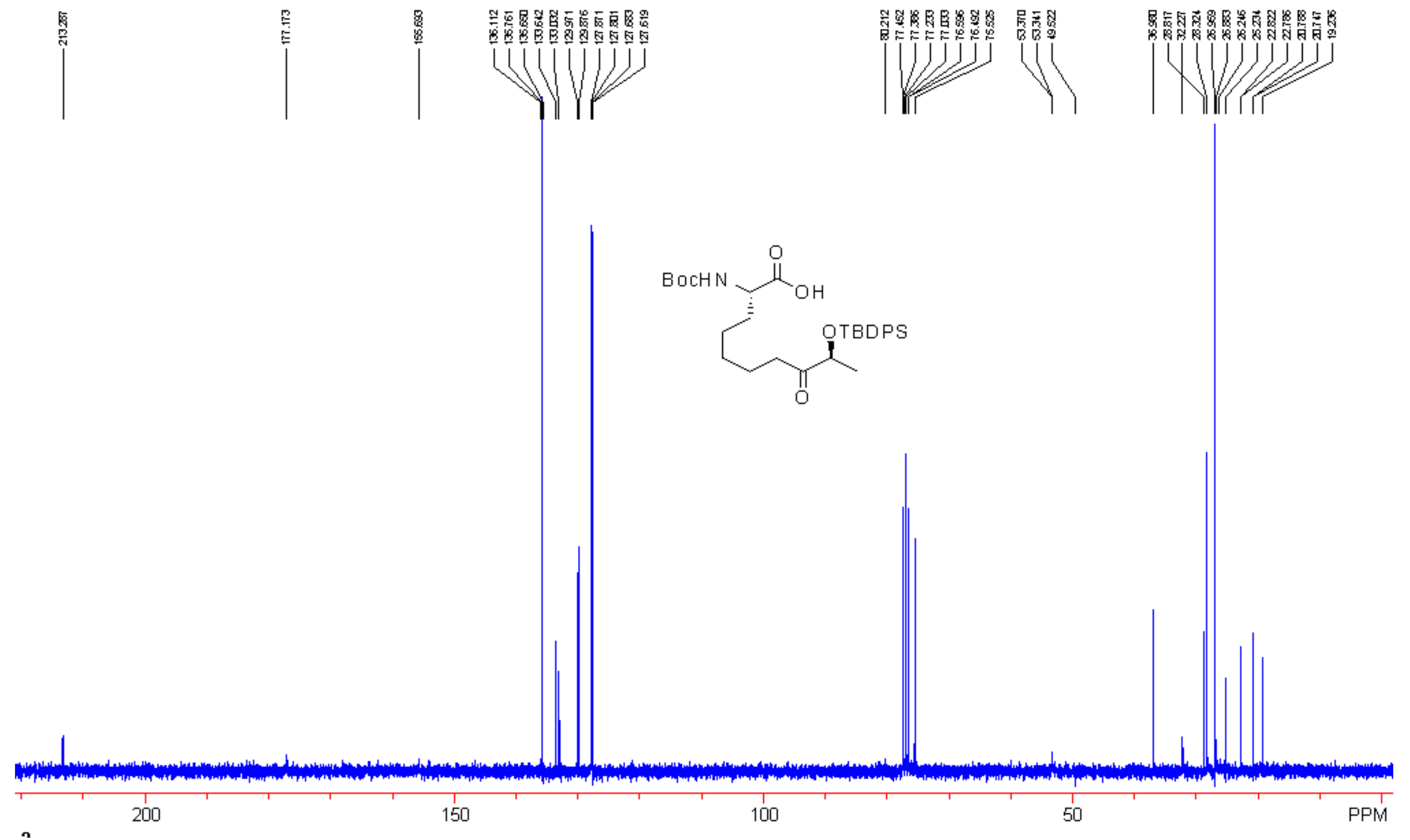




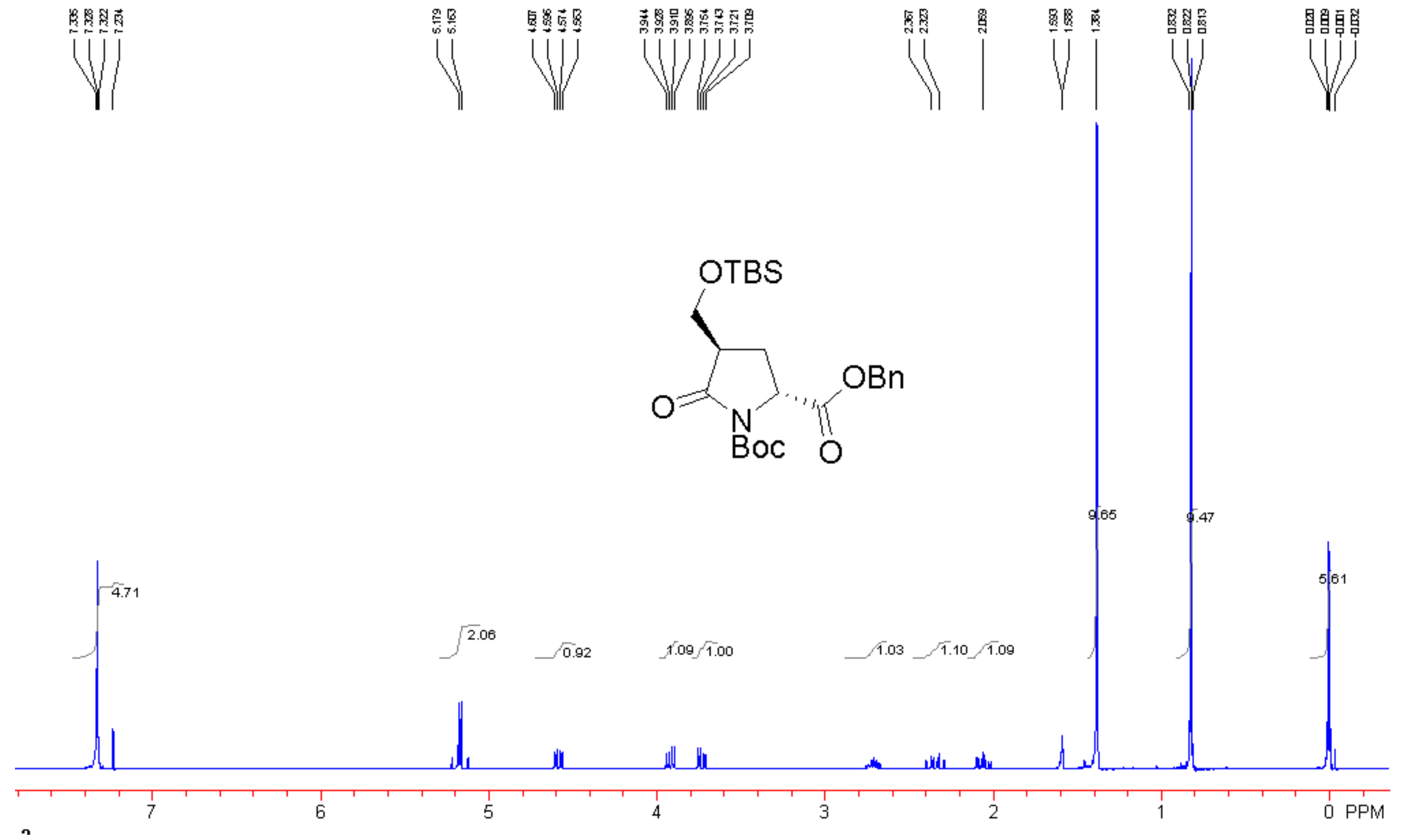



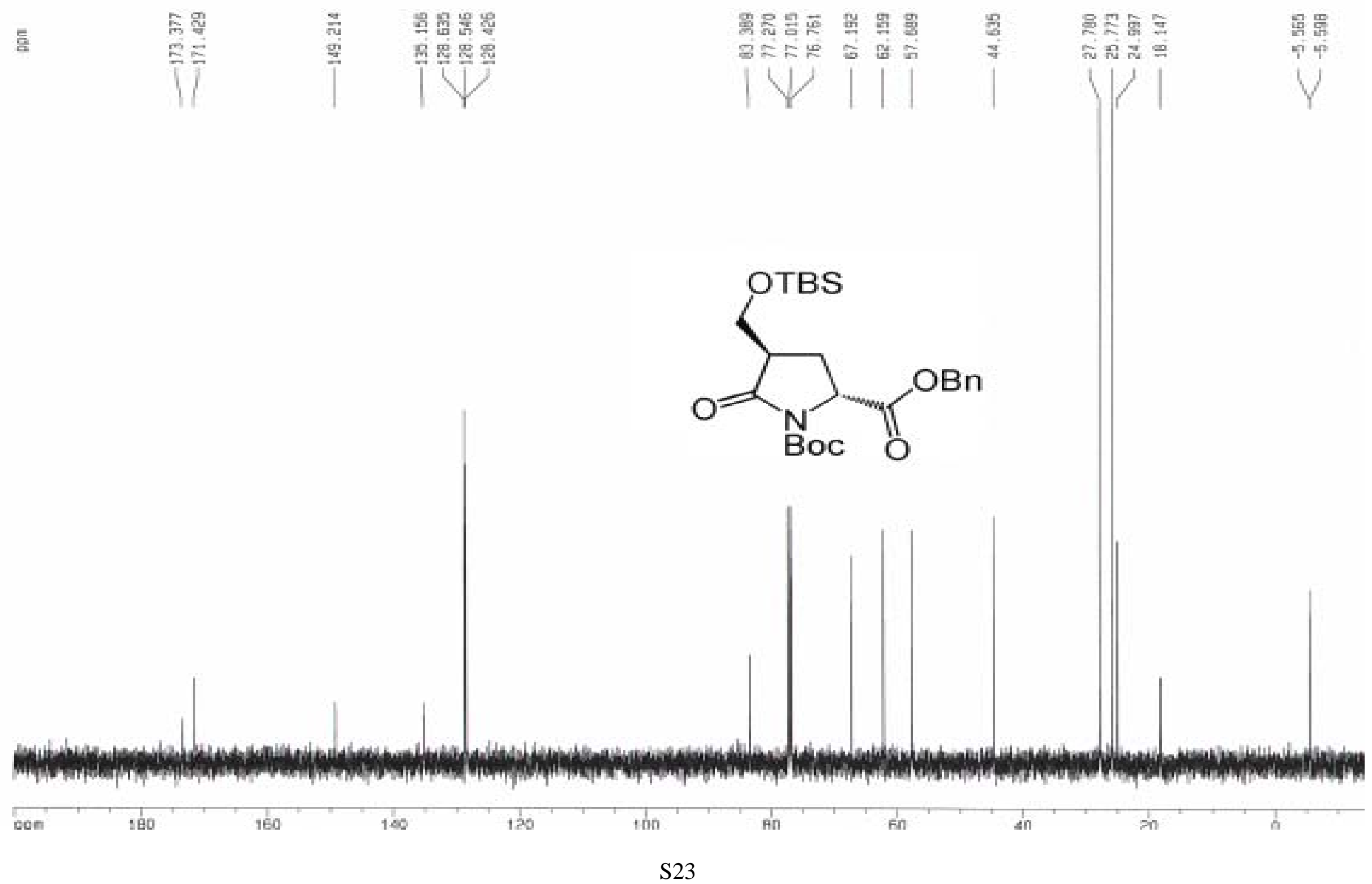


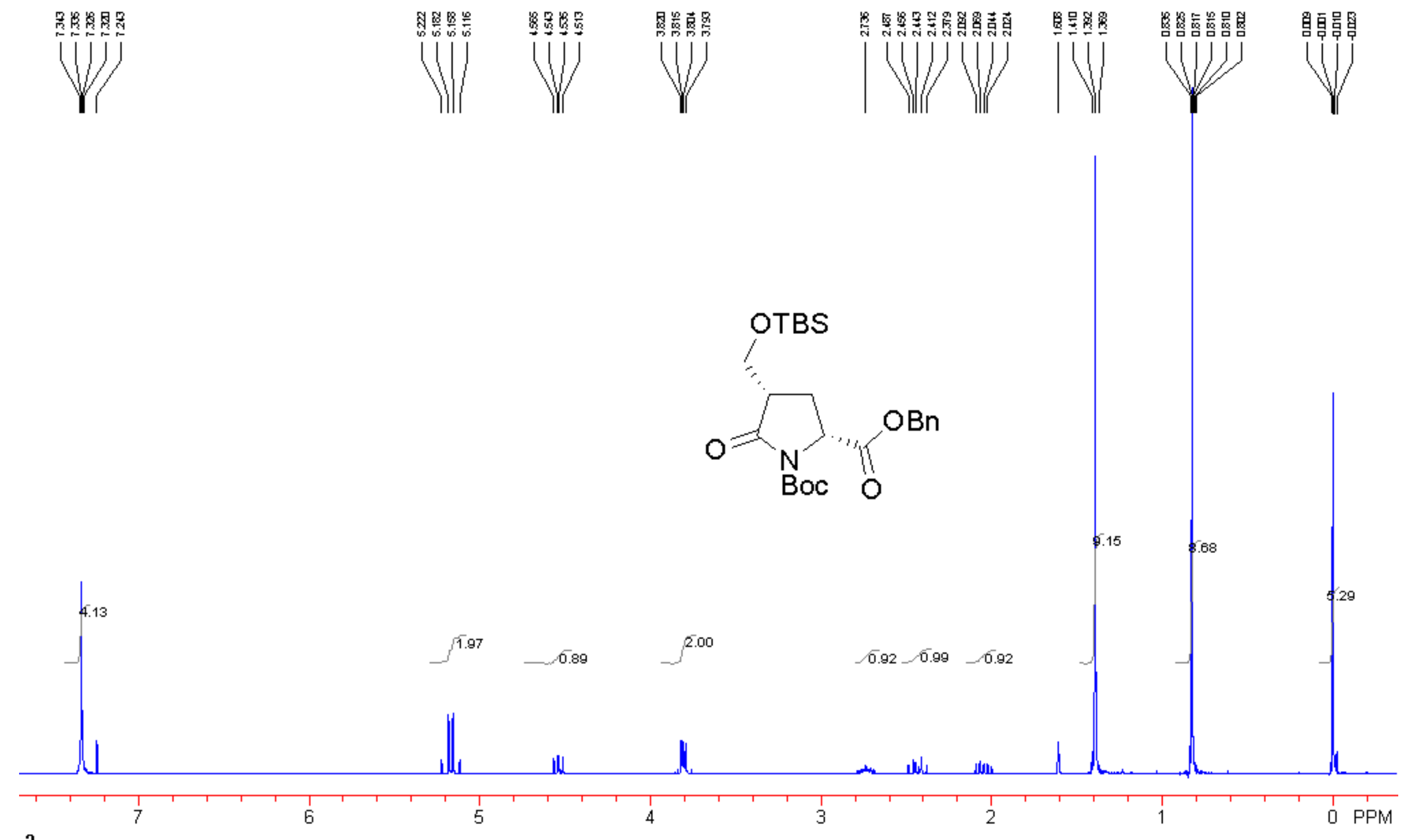




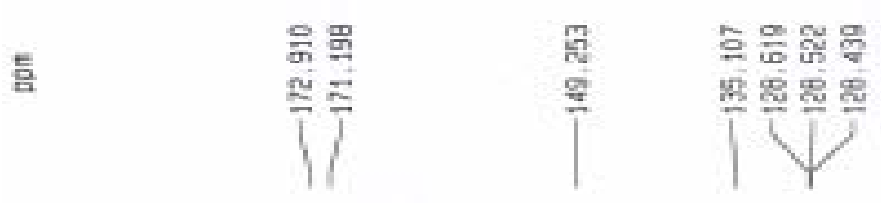

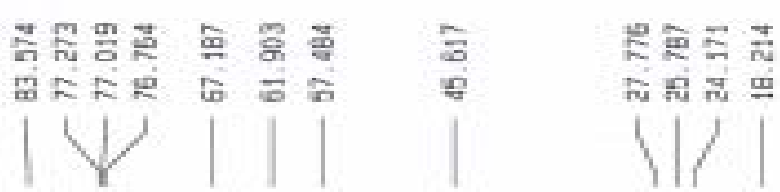

s

54

V

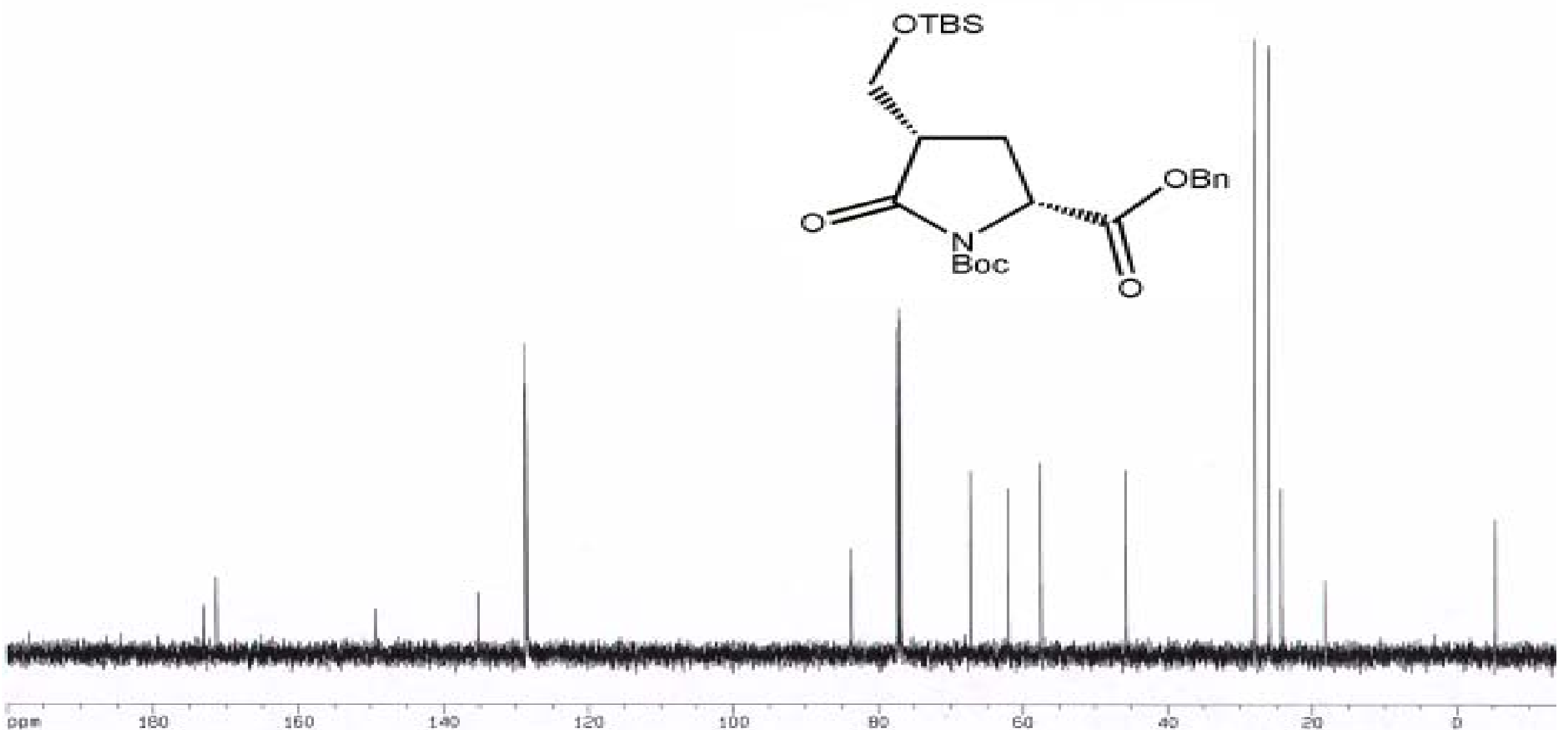




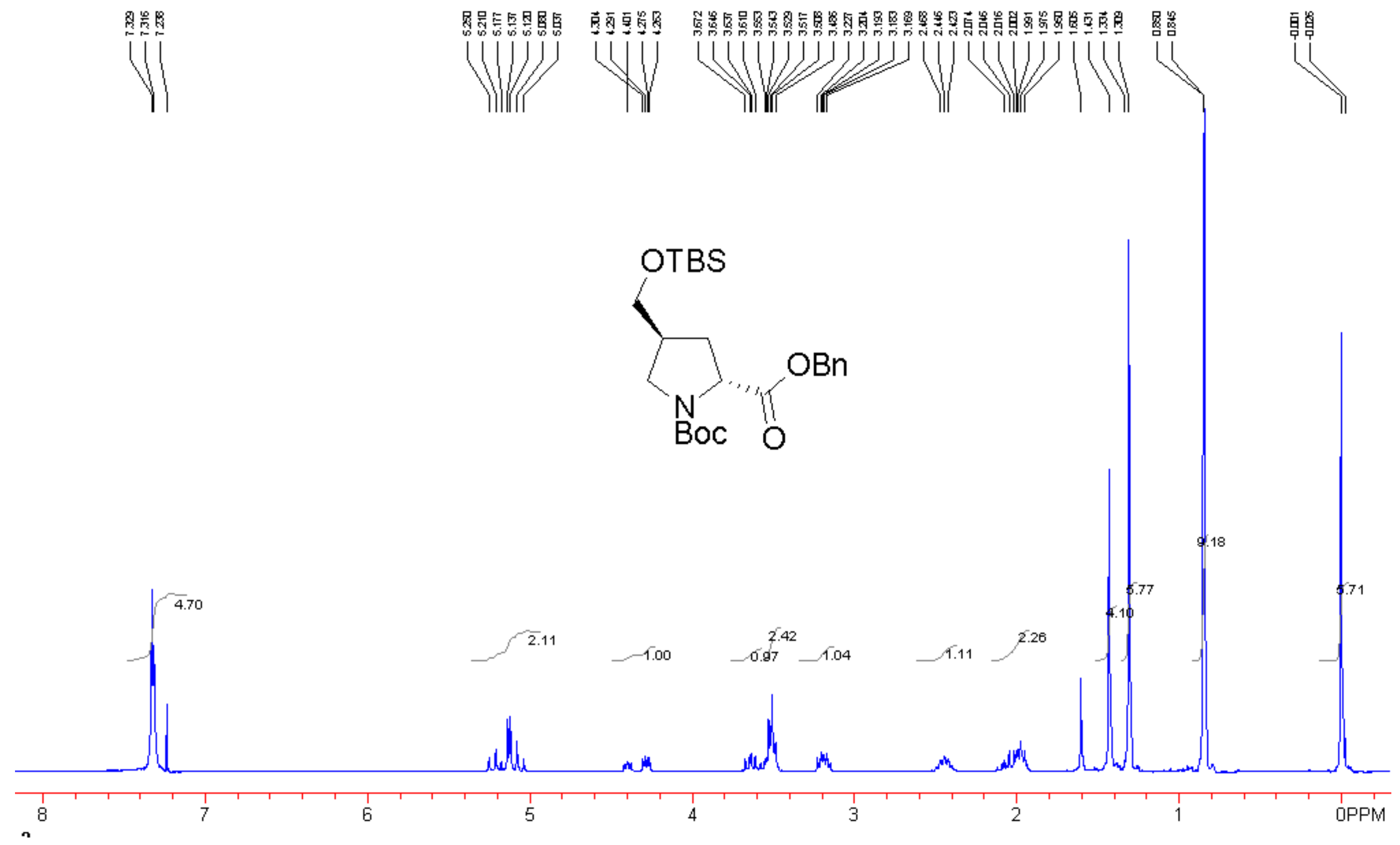




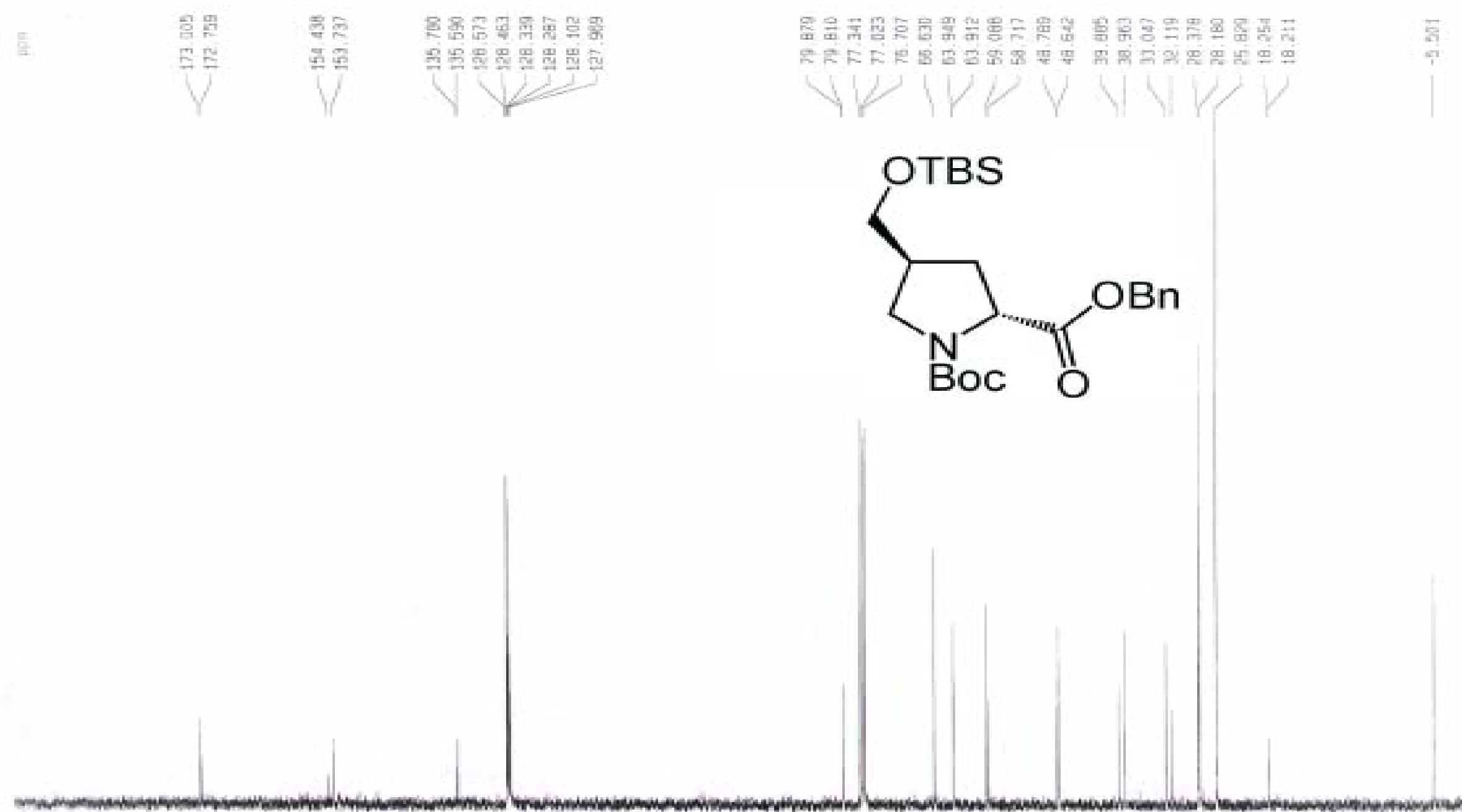




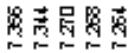

( 1

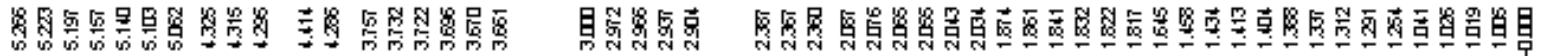

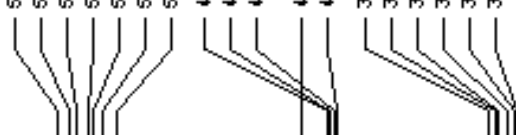

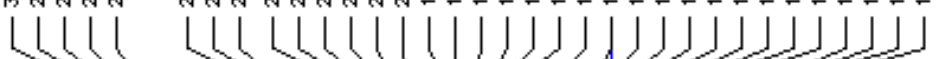

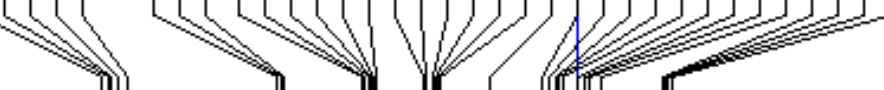

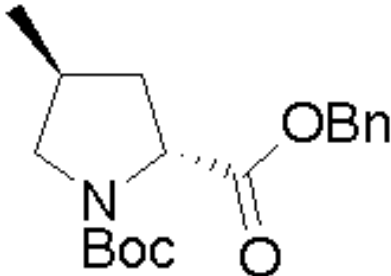

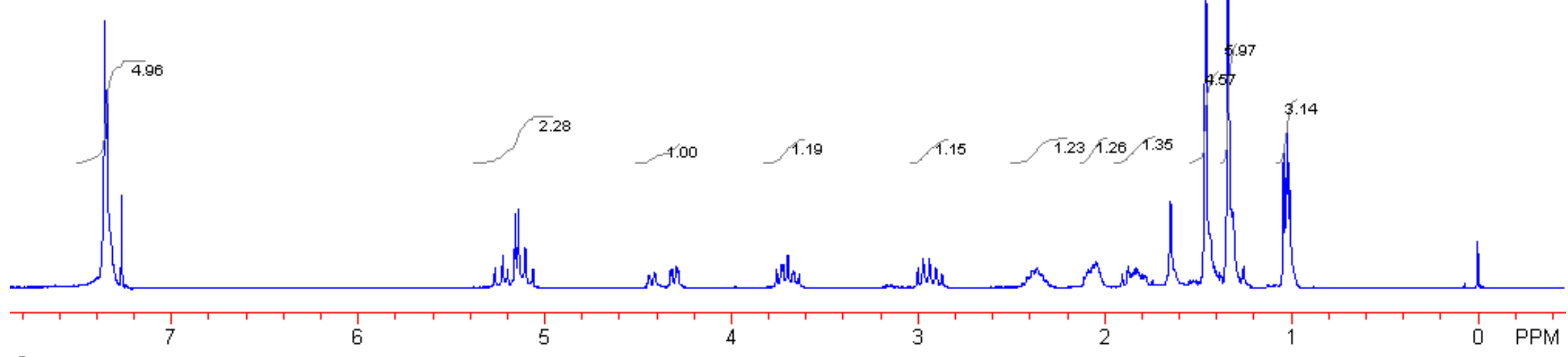



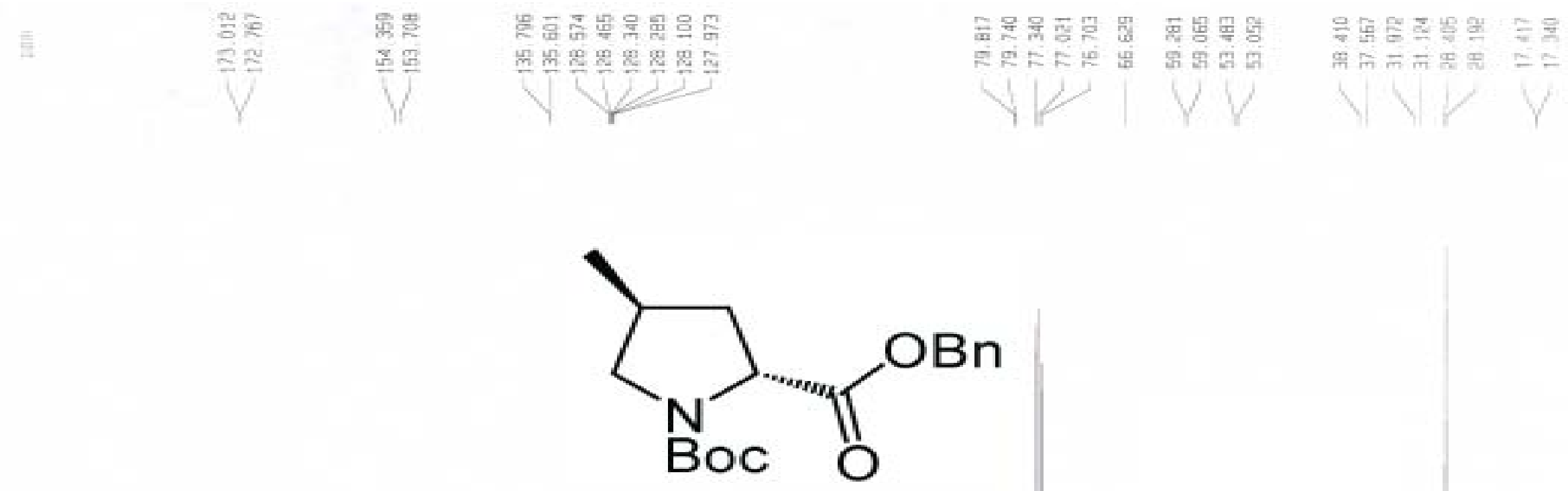

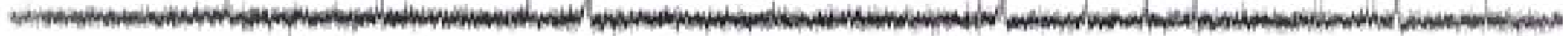

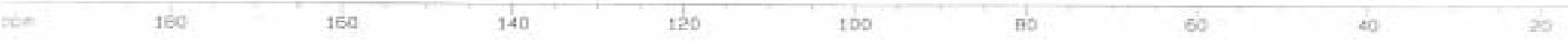




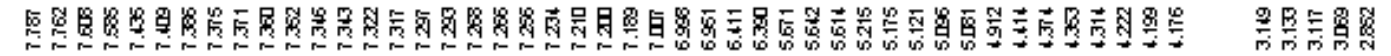

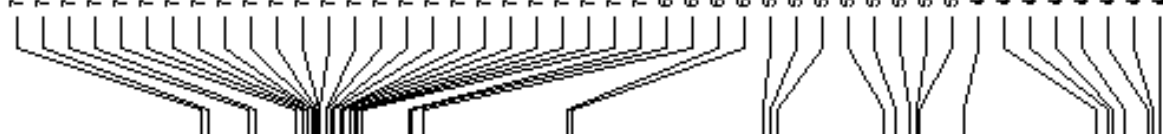

Liili

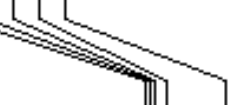

\&

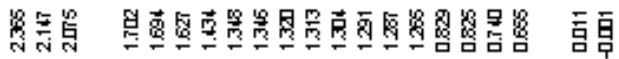
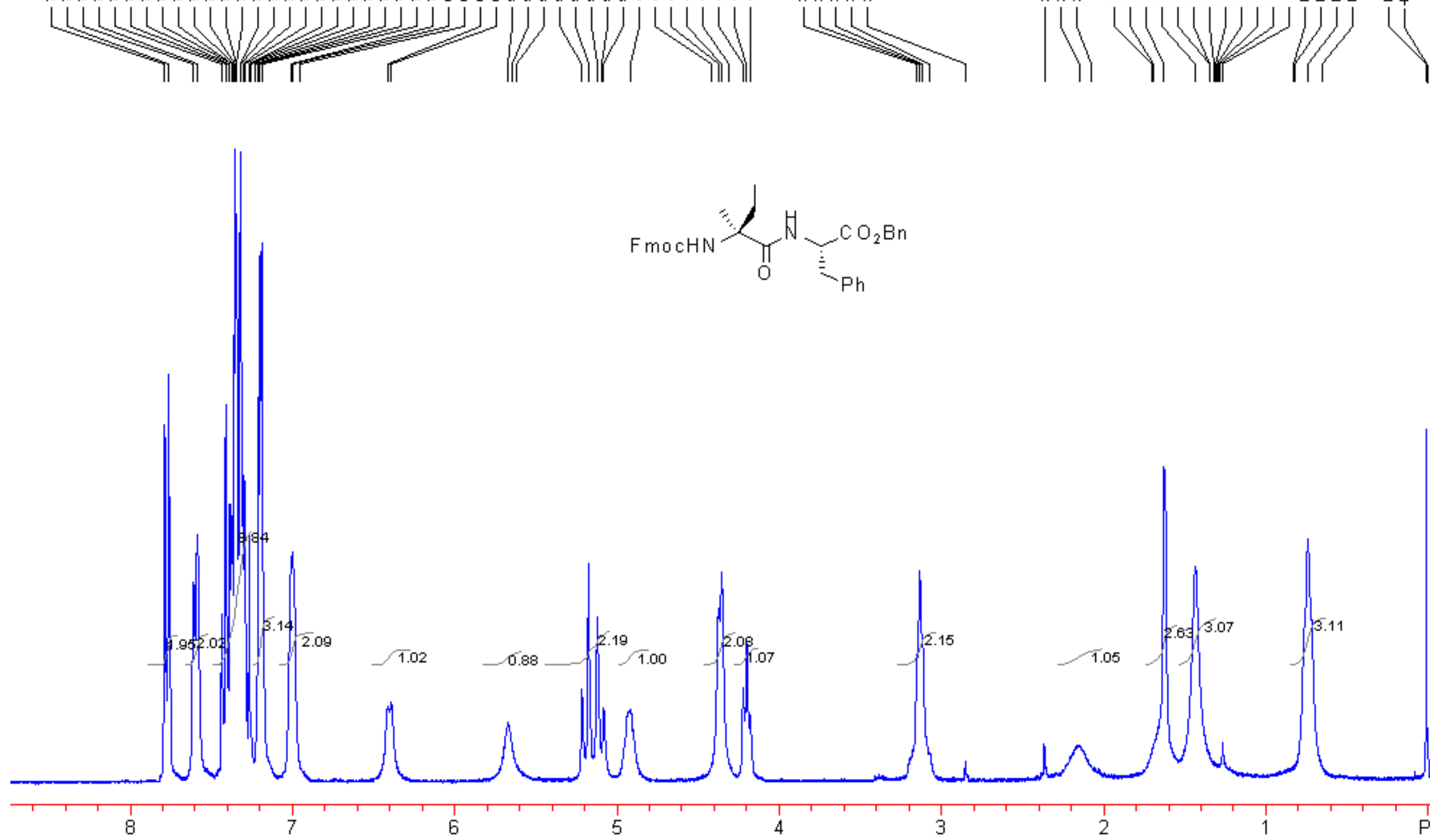

7

6
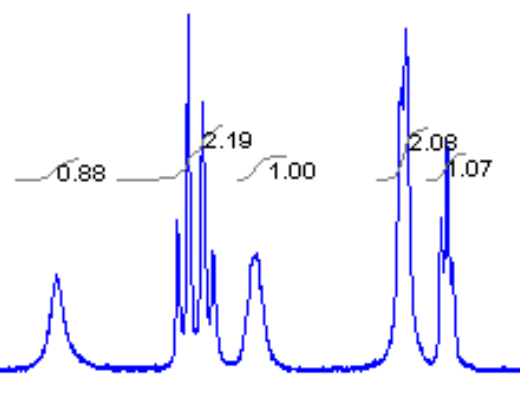

5

4

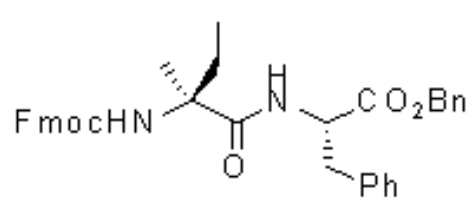



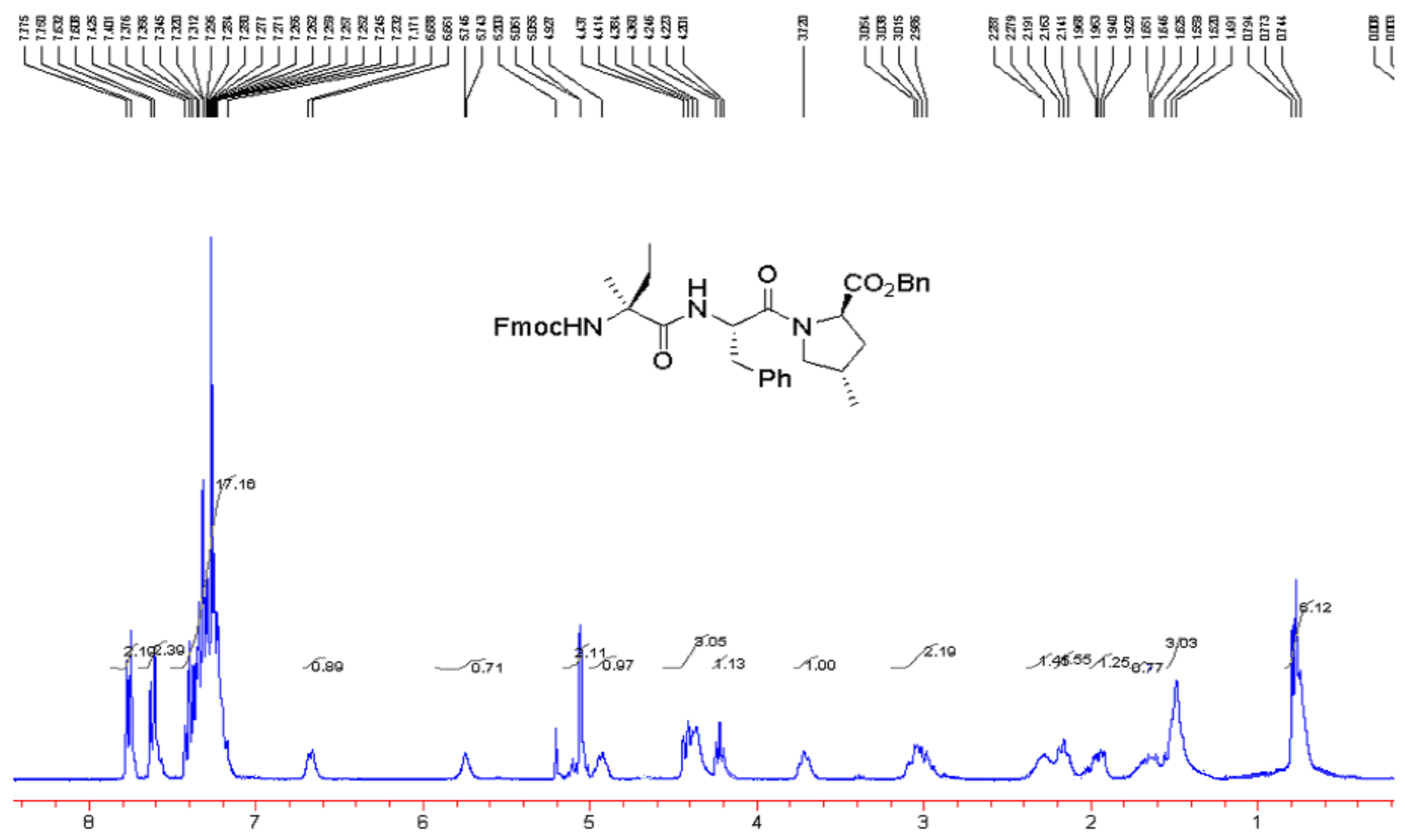


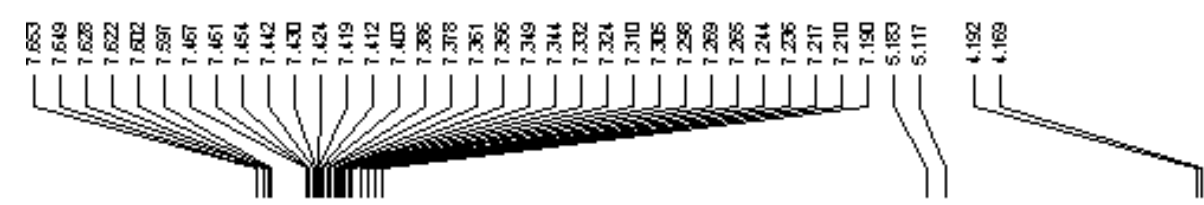

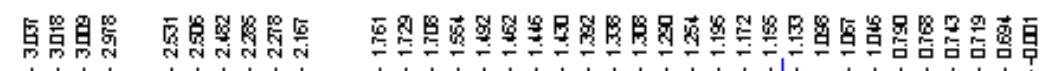

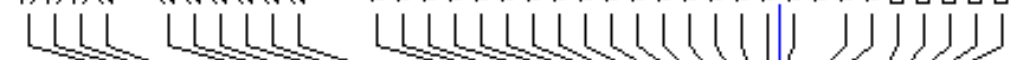
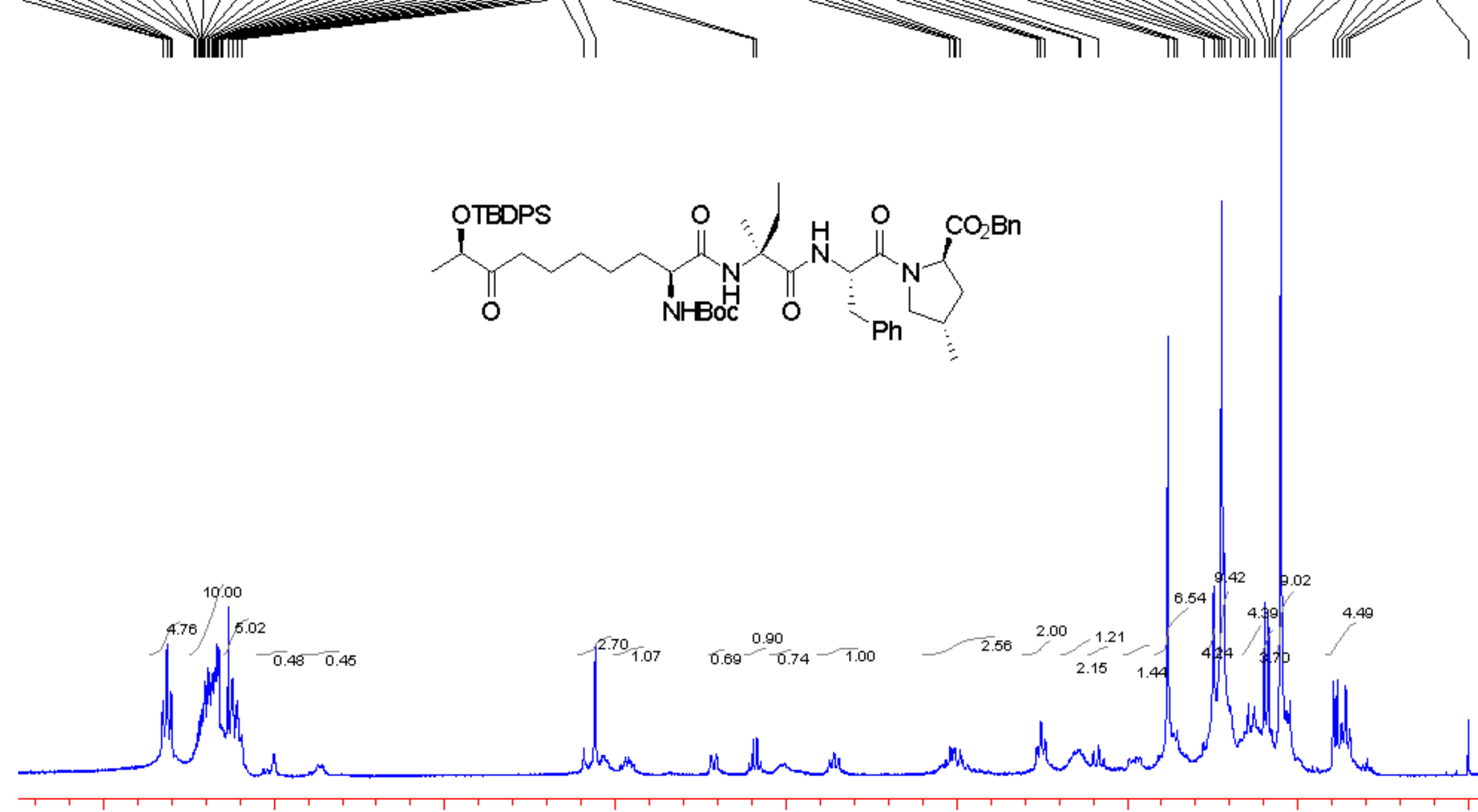

3

2

PPM 

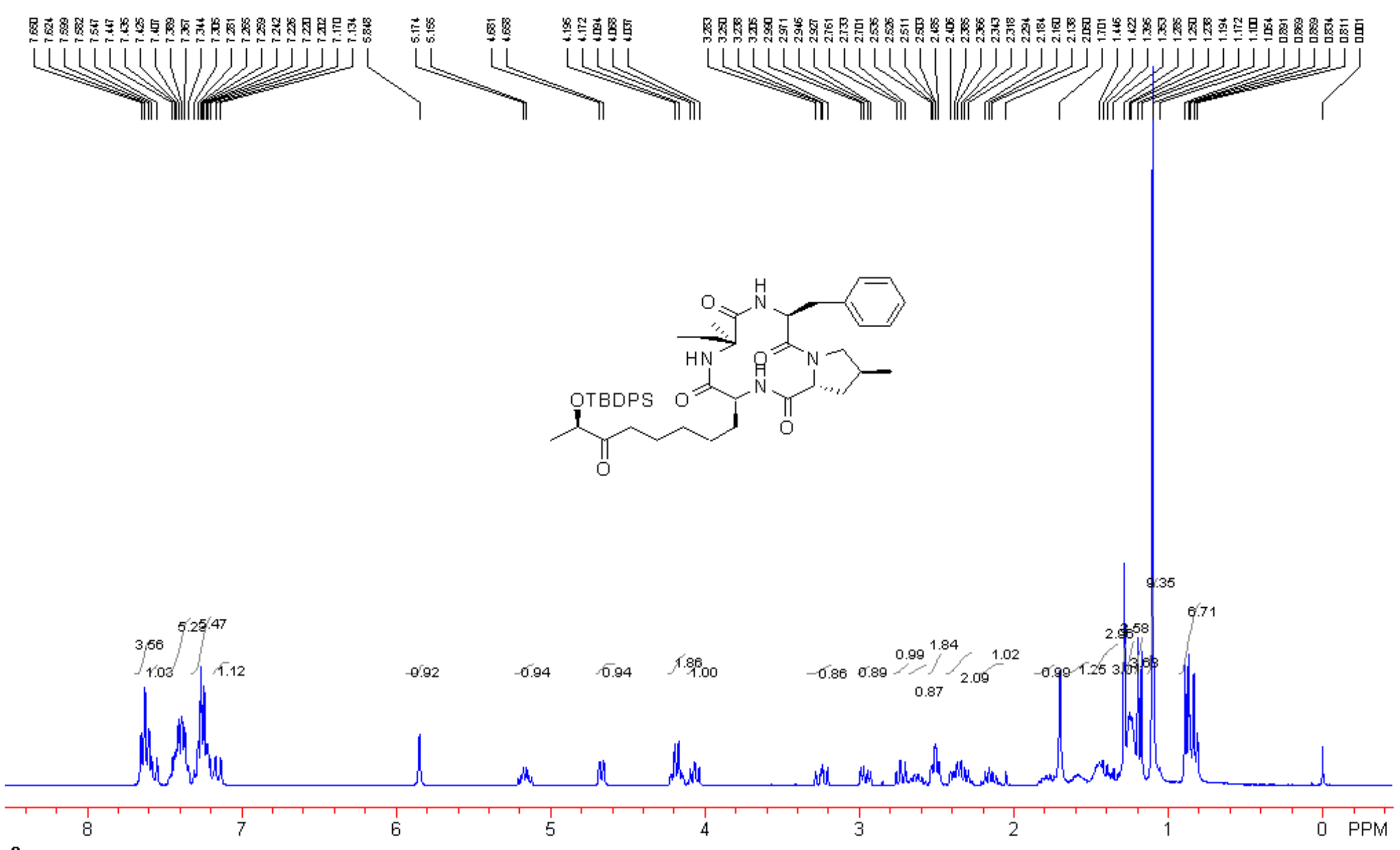


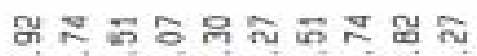
분

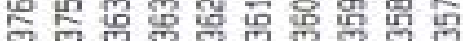

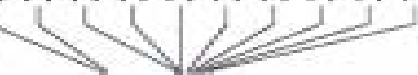

m

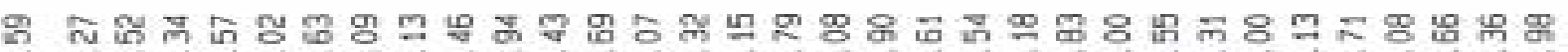

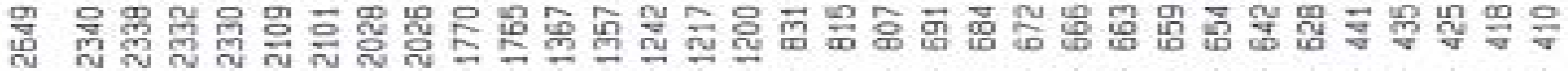

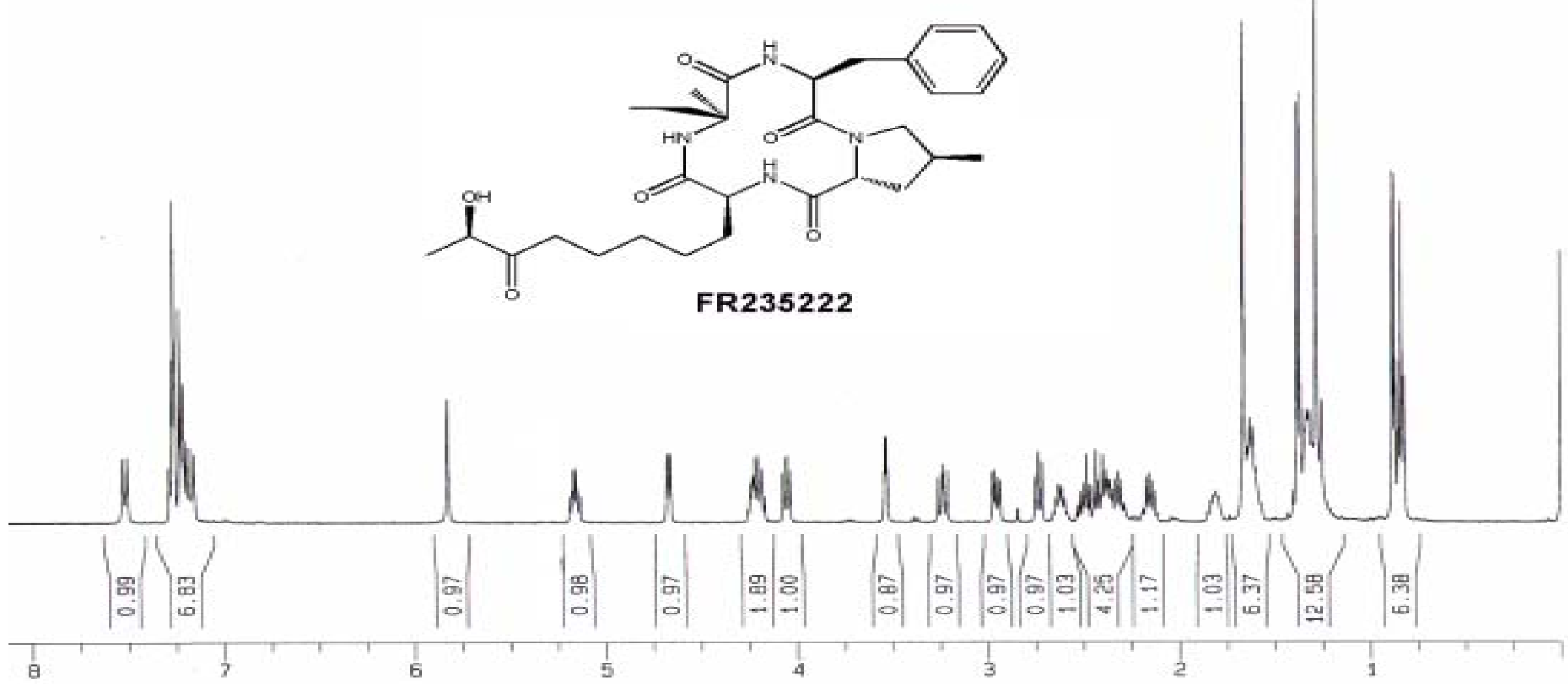




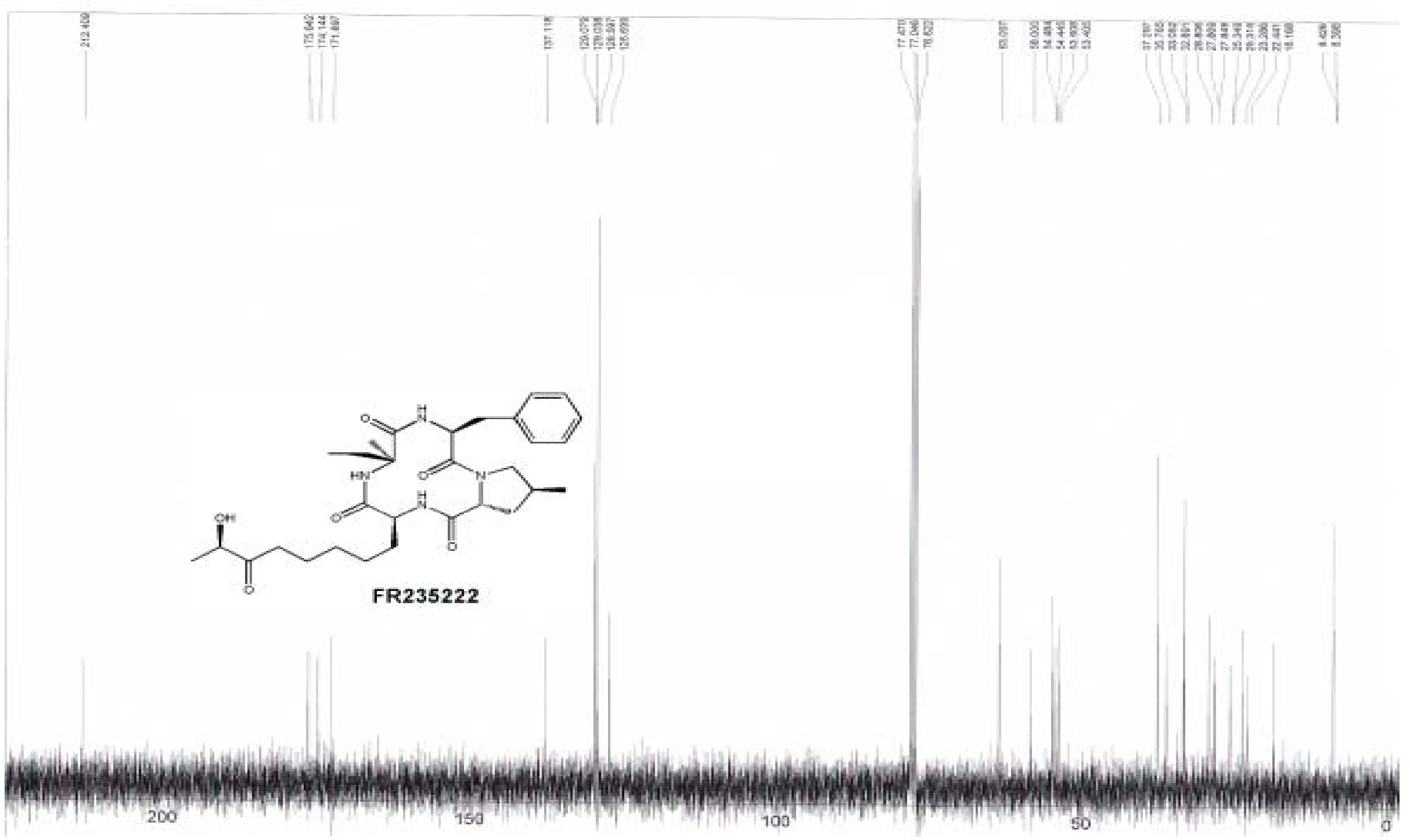

